\title{
Relative timing of precipitation and ocean circulation changes in the western equatorial Atlantic over the last $\mathbf{4 5} \mathrm{kyr}$
}

\author{
Claire Waelbroeck $^{1}$, Sylvain Pichat ${ }^{2,3}$, Evelyn Böhm $^{1}$, Bryan C. Lougheed $^{1}$, Davide Faranda ${ }^{1}$, Mathieu Vrac ${ }^{1}$, \\ Lise Missiaen $^{1}$, Natalia Vazquez Riveiros ${ }^{1,4}$, Pierre Burckel $^{5}$, Jörg Lippold ${ }^{6}$, Helge W. Arz ${ }^{7}$, Trond Dokken ${ }^{8}$, \\ François Thil ${ }^{1}$, and Arnaud Dapoigny ${ }^{1}$ \\ ${ }^{1}$ LSCE/IPSL, Laboratoire CNRS-CEA-UVSQ, 91198 Gif-sur-Yvette, France \\ ${ }^{2}$ Laboratoire de Géologie de Lyon (LGL-TPE), Ecole Normale Supérieure de Lyon, Université de Lyon, \\ CNRS UMR5276, 69007 Lyon, France \\ ${ }^{3}$ Climate Geochemistry Department, Max Planck Institute for Chemistry, Mainz, Germany \\ ${ }^{4}$ Ifremer, Unité de Geosciences Marines, 29280 Plouzané, France \\ ${ }^{5}$ IPGP, Université Sorbonne, 75238 Paris, France \\ ${ }^{6}$ Institute of Earth Sciences, Heidelberg University, Im Neuenheimer Feld 234, 69120 Heidelberg, Germany \\ ${ }^{7}$ Leibniz-Institute for Baltic Sea Research Warnemünde, Seestrasse 15, 18119 Rostock, Germany \\ ${ }^{8}$ Uni Research and Bjreknes Centre for Climate Research, Nygårdsgaten 112, 5008 Bergen, Norway
}

Correspondence: Claire Waelbroeck (claire.waelbroeck@1sce.ipsl.fr)

Received: 2 March 2018 - Discussion started: 19 March 2018

Revised: 1 August 2018 - Accepted: 27 August 2018 - Published: 18 September 2018

\begin{abstract}
Thanks to its optimal location on the northern Brazilian margin, core MD09-3257 records both ocean circulation and atmospheric changes. The latter occur locally in the form of increased rainfall on the adjacent continent during the cold intervals recorded in Greenland ice and northern North Atlantic sediment cores (i.e., Greenland stadials). These rainfall events are recorded in MD09-3257 as peaks in $\ln (\mathrm{Ti} / \mathrm{Ca})$. New sedimentary $\mathrm{Pa} / \mathrm{Th}$ data indicate that mid-depth western equatorial water mass transport decreased during all of the Greenland stadials of the last $40 \mathrm{kyr}$. Using cross-wavelet transforms and spectrogram analysis, we assess the relative phase between the MD09-3257 sedimentary $\mathrm{Pa} / \mathrm{Th}$ and $\ln (\mathrm{Ti} / \mathrm{Ca})$ signals. We show that decreased water mass transport between a depth of $\sim 1300$ and $2300 \mathrm{~m}$ in the western equatorial Atlantic preceded increased rainfall over the adjacent continent by 120 to $400 \mathrm{yr}$ at Dansgaard-Oeschger (D-O) frequencies, and by 280 to $980 \mathrm{yr}$ at Heinrich-like frequencies.

We suggest that the large lead of ocean circulation changes with respect to changes in tropical South American precipitation at Heinrich-like frequencies is related to the effect of a positive feedback involving iceberg discharges in the North Atlantic. In contrast, the absence of widespread ice rafted
\end{abstract}

detrital layers in North Atlantic cores during D-O stadials supports the hypothesis that a feedback such as this was not triggered in the case of $\mathrm{D}-\mathrm{O}$ stadials, with circulation slowdowns and subsequent changes remaining more limited during D-O stadials than Heinrich stadials.

\section{Introduction}

Rapid changes in ocean circulation and climate have been observed in marine sediments and polar ice cores over the last glacial and deglacial period (e.g., Johnsen et al., 1992; Vidal et al., 1997). These observations demonstrate that the ocean's current mode of circulation is not unique and can rapidly switch between dramatically different states, in conjunction with climate changes. Furthermore, these observations highlight the non-linear character of the climate system.

Documenting the precise timing and sequence of events in proxy records is a prerequisite for understanding the processes responsible for rapid climate changes and improving climate models' predictive skills. However, the task is complicated by the difficulty of deriving precise age models for marine sediment cores. When marine cores are radiocarbon 
dated, uncertainties can arise from bioturbation biases (e.g., Lougheed et al., 2018) and changes in past surface reservoir ages (Waelbroeck et al., 2001; Thornalley et al., 2011). In the best cases, when changes in past surface reservoir ages and bioturbation biases remain limited, dating uncertainties mainly derive from the calibration of radiocarbon ages into calendar ages.

In these cases, errors are less than $150 \mathrm{yr}$ for the time interval spanning 0-11 calendar kyr BP (noted ka), about $400 \mathrm{yr}$ for the 11-30 ka interval, and 600 to $1100 \mathrm{yr}$ for the $30-40 \mathrm{ka}$ interval (Reimer et al., 2013). Thus, minimum relative dating errors between records from different marine sediment cores, or between marine and ice cores records, reach $500 \mathrm{yr}$ at the end of the last deglaciation and increase from 500 to $1500 \mathrm{yr}$, for increasing ages between 11 and $40 \mathrm{ka}$. Therefore, it is not possible to quantify leads or lags of less than $500 \mathrm{yr}$ between records from different marine cores, or between marine and ice core records.

Here we take advantage of the fact that the northern Brazilian margin core MD09-3257 records both ocean circulation and atmospheric changes. On the one hand, we reconstruct ocean circulation changes based on new sedimentary $\mathrm{Pa} / \mathrm{Th}$ data and on epifaunal benthic isotopic ratios. On the other hand, sediment Ti / Ca measured by X-ray fluorescence reflects past changes in rainfall on the adjacent continent (Arz et al., 1998; Jaeschke et al., 2007). Because $\mathrm{Pa} / \mathrm{Th}$ and $\mathrm{Ti} / \mathrm{Ca}$ are recorded in the same core, their relative phasing can be examined with virtually no relative dating uncertainty.

We first present the new sedimentary $\mathrm{Pa} / \mathrm{Th}$ data and their relation to changes in mid-depth water transport in the western equatorial Atlantic over the last $45 \mathrm{kyr}$. We then precisely assess the relative phasing between the changes in rainfall and ocean circulation recorded in core MD09-3257.

\section{Material and methods}

\subsection{Core locations}

Core MD09-3257 $\left(04^{\circ} 14.7^{\prime} \mathrm{S}, 36^{\circ} 21.2^{\prime} \mathrm{W}, 2344 \mathrm{~m}\right)$ was recovered in 2009 from the northern Brazilian margin during the R/V Marion Dufresne cruise MD173/RETRO3 at approximately the same position as core GeoB3910-2 $\left(04^{\circ} 14.7^{\prime} \mathrm{S}, 36^{\circ} 20.7^{\prime} \mathrm{W}, 2362 \mathrm{~m}\right.$ ) (Arz et al., 2001; Jaeschke et al., 2007). The improved recovery of deep-sea sediments with little or no deformation of sediment layers was achieved thanks to the systematic use of the CINEMA software (Bourillet et al., 2007; Woerther and Bourillet, 2005). This software computes the amplitude and duration of the aramid cable elastic recoil, as well as the piston displacement throughout the coring phase, accounting for the length of the cable (water depth) and total weight of the coring system.

At present, the northern Brazilian margin is bathed by southward flowing upper North Atlantic Deep Water (NADW) at these depths (Lux et al., 2001; Schott et al., 2003; Rhein et al., 2015) (Fig. 1). The southward advection of dense waters formed at higher northern latitudes is channeled through the western boundary current (Rhein et al., 2015), meaning that our sediment cores are ideally located to detect changes in the transport of northern-sourced waters above a depth of $2500 \mathrm{~m}$.

\subsection{X-ray fluorescence spectrometry}

Elemental composition was measured by employing nondestructive, profiling X-ray fluorescence (XRF) spectrometry. The measurements were made using an AVAATECH XRF core scanner at the Bjerkness Centre for Climate Research, Bergen (Norway) at intervals of $0.5 \mathrm{~mm}$ on core MD09-3257, and using a CORTEX XRF scanner at the Bremen Integrated Ocean Drilling Program core repository at intervals of $0.4 \mathrm{~cm}$ on core GeoB3910-2 (Jaeschke et al., 2007). This automated scanning method allows for a rapid qualitative determination of the geochemical composition of the sediment at very high resolution (Croudace and Rothwell, 2015).

\subsection{Chronology}

Ti / Ca records from core MD09-3257 and core GeoB39102 exhibit marked peaks corresponding to increased terrigenous input due to enhanced precipitation and runoff from the continent (Arz et al., 1998; Jaeschke et al., 2007) (Fig. 2). These precipitation events are also recorded in South American speleothems, and have been shown to correspond to North Atlantic cold stadial periods (Cheng et al., 2013). The core GeoB3910-2 radiocarbon $\left({ }^{14} \mathrm{C}\right)$ age model shows that increases in sedimentary $\mathrm{Ti} / \mathrm{Ca}$ are indeed synchronous with decreases in South American speleothem $\delta^{18} \mathrm{O}$ (Burckel et al., 2015). Based on the observed synchronicity, composite age models of core MD09-3257 and GeoB3910-2 have been developed using ${ }^{14} \mathrm{C}$ dating for the past $35 \mathrm{kyr}$, combined with the alignment of sediment $\mathrm{Ti} / \mathrm{Ca}$ increases with decreases in speleothem $\delta^{18} \mathrm{O}$ for the older portion of the cores (Vazquez Riveiros et al., 2018); thus, speleothem ages beyond $35 \mathrm{ka}$ could be transferred to the marine cores. The chronology of core GeoB3910-2 is based on 17 monospecific radiocarbon dates between 0 and $31 \mathrm{ka}$ (Burckel et al., 2015; Jaeschke et al., 2007). The Ti / Ca record of core GeoB39102 was aligned to that of core MD09-3257 in order to transfer the radiocarbon dates of GeoB3910-2 over the interval from 12 to $36 \mathrm{ka}$ to this nearby core. In addition, five monospecific radiocarbon dates over 1-21 ka were directly obtained from core MD09-3257. Speleothem tie points were used to derive the chronology of this core over the period from 38 to $48 \mathrm{ka}$ (Tables S1 and S2 in the Supplement) (Vazquez Riveiros et al., 2018). All radiocarbon dates were converted to calendar dates using the OxCal 4.2 software, the IntCal13 calibration curve (Reimer et al., 2013), and a surface water reservoir age of $550 \pm 50 \mathrm{yr}$ over $0-18 \mathrm{ka}$ (Key et al., 2004), and of $750 \pm 250$ yr over $18-31 \mathrm{ka}$ (Freeman et al., 2016). The final age models of cores GeoB3910-2 and MD09-3257 were ob- 
(a)

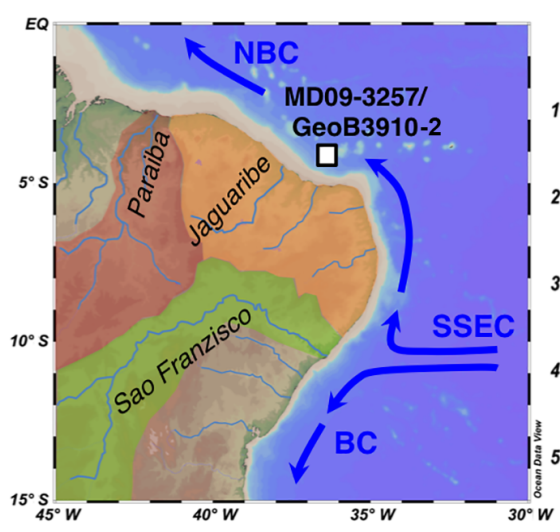

(b)

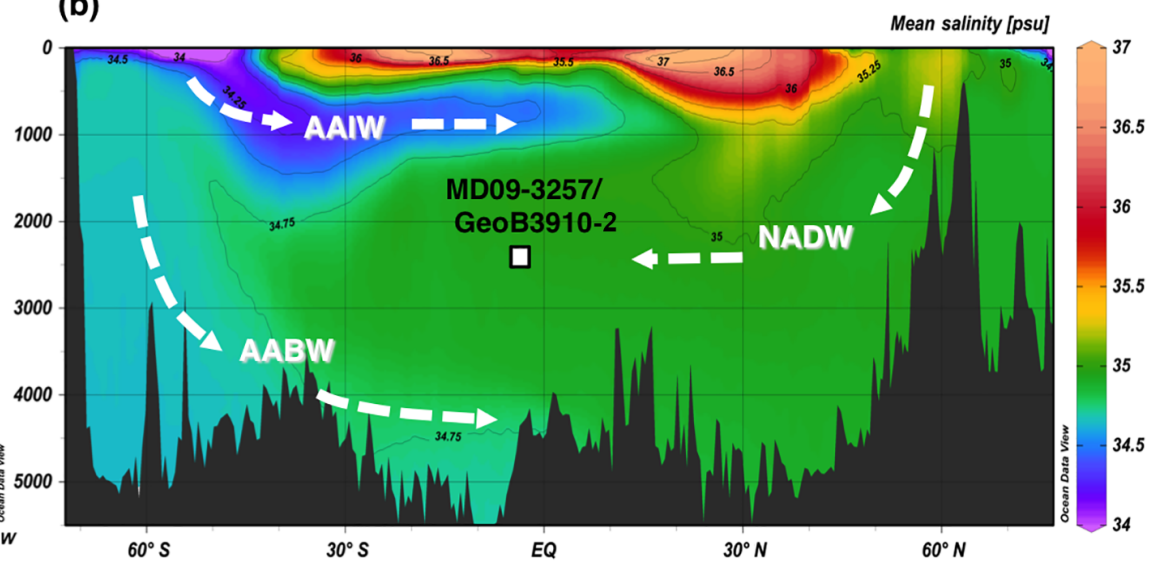

Figure 1. (a) Map showing the position of the main Brazilian rivers and surface currents that could influence the terrigenous input at the study site; the study site is indicated by a white square. The orange area represents the catchment area of the local rivers directly delivering sediments to the study site, and the green area represents the catchment area of the Sao Franzisco River (Milliman et al., 1975). NBC stands for North Brazil Current, SSEC stands for Southern South Equatorial Current and BC stands for Brazil Current. (b) Salinity section showing the core site and the main water masses in the modern Atlantic Ocean. NADW stands for North Atlantic Deep Water, AAIW stands for Antarctic Intermediate Water and AABW stands for Antarctic Bottom Water.

tained using a P_Sequence depositional model (Bronk Ramsey, 2008), i.e., a Bayesian algorithm producing posterior probability distributions for each core depth (Tables S1 and S2) (Vazquez Riveiros et al., 2018).

In the present study, the GeoB3910-2 age scale for the 32$50 \mathrm{ka}$ interval was further adjusted by precise alignment of GeoB3910-2 XRF to the MD09-3257 XRF signal (Fig. S1 in the Supplement), which produced a composite record from these two nearby cores. Given that both XRF signals are virtually identical and measured at very high resolution (sampling step $\leq 0.5 \mathrm{~cm}$ ), the mean relative dating uncertainty between the two cores is extremely small (less than $105 \mathrm{yr}$; Fig. S1).

Here, we use XRF $\ln (\mathrm{Ti} / \mathrm{Ca})$ rather than $\mathrm{Ti} / \mathrm{Ca}$ because log-ratios provide a unique measure of sediment composition, in contrast to simple ratios, which are asymmetric (i.e., conclusions based on evaluation of $\mathrm{A} / \mathrm{B}$ cannot be directly translated into equivalent statements about $\mathrm{B} / \mathrm{A}$ ) and suffer from statistical intractability (Weltje and Tjallingii, 2008). We adopt the same terminology as Burckel et al. (2015) and define the larger $\ln (\mathrm{Ti} / \mathrm{Ca}$ ) peaks as precipitation events PE0 to PE5, with PE0 occurring during the Younger Dryas, and PE1 to PE5 occurring during Heinrich stadials 1 to 5 (Fig. 2). What we refer to as Heinrich stadials are strictly those stadials characterized by the occurrence of iceberg discharges in the mid- to high-latitude North Atlantic. We refer to smaller $\ln (\mathrm{Ti} / \mathrm{Ca})$ peaks corresponding to $\mathrm{D}-\mathrm{O}$ stadials using the Greenland stadial numbering system, as defined by Rasmussen et al. (2014).

\subsection{Benthic isotopes}

Epifaunal benthic foraminifers of the Cibicides wuellerstorfi species were handpicked in the $>150 \mu \mathrm{m}$ size fraction (Vazquez Riveiros et al., 2018). Core MD09-3257 $C$. wuellerstorf ${ }^{13} \mathrm{C} /{ }^{12} \mathrm{C}\left(\delta^{13} \mathrm{C}\right.$, expressed in \%o versus Vienna Pee Dee Belemnite, VPDB) was measured at the LSCE on Finnigan DELTAplus and Elementar Isoprime mass spectrometers on samples of one to three specimens. VPDB is defined with respect to the NBS-19 calcite standard $\left(\delta^{18} \mathrm{O}=-2.20\right.$ and $\delta^{13} \mathrm{C}=+1.95 \%$ ). The mean external reproducibility $(1 \sigma)$ of carbonate standards is $\pm 0.03 \%$ or $\delta^{13} \mathrm{C}$; measured NBS- $18 \delta^{18} \mathrm{O}$ is $-23.27 \pm 0.10$ and $\delta^{13} \mathrm{C}$ is $-5.01 \pm 0.03 \%$ o VPDB. Core GeoB3910-2 C. wuellerstorfi $g \delta{ }^{13} \mathrm{C}$ was measured at the University of Bremen, Germany, on a Finnigan MAT 252 mass spectrometer on samples of one to five specimens (Heil, 2006), with a mean external reproducibility $(1 \sigma)$ for carbonate standards of $\pm 0.05 \%$ o for $\delta^{13} \mathrm{C}$. A composite high-resolution benthic isotopic record was generated by combining isotopic data from the upper $294 \mathrm{~cm}$ of core MD09-3257 (covering the last $32 \mathrm{kyr}$ ) with isotopic data from the interval from 246 to $451 \mathrm{~cm}$ in core GeoB39102 for the older part of the record (Vazquez Riveiros et al., 2018).

The ${ }^{13} \mathrm{C} /{ }^{12} \mathrm{C}$ isotopic ratio $\left({ }^{13} \mathrm{C}\right.$, expressed in per mil $\% o$ - versus VPDB) of the epifaunal benthic foraminifer $C$. wuellerstorfi has been shown to record the $\delta^{13} \mathrm{C}$ of bottomwater dissolved inorganic carbon (DIC) with minor isotopic fractionation (Duplessy et al., 1984; Zahn et al., 1986; Schmittner et al., 2017). A water mass' initial DIC isotopic concentration is governed by surface productivity in its formation region (i.e., the preferential consumption of ${ }^{12} \mathrm{C}$ by primary productivity, which increases dissolved $\delta^{13} \mathrm{C}$ ), as 


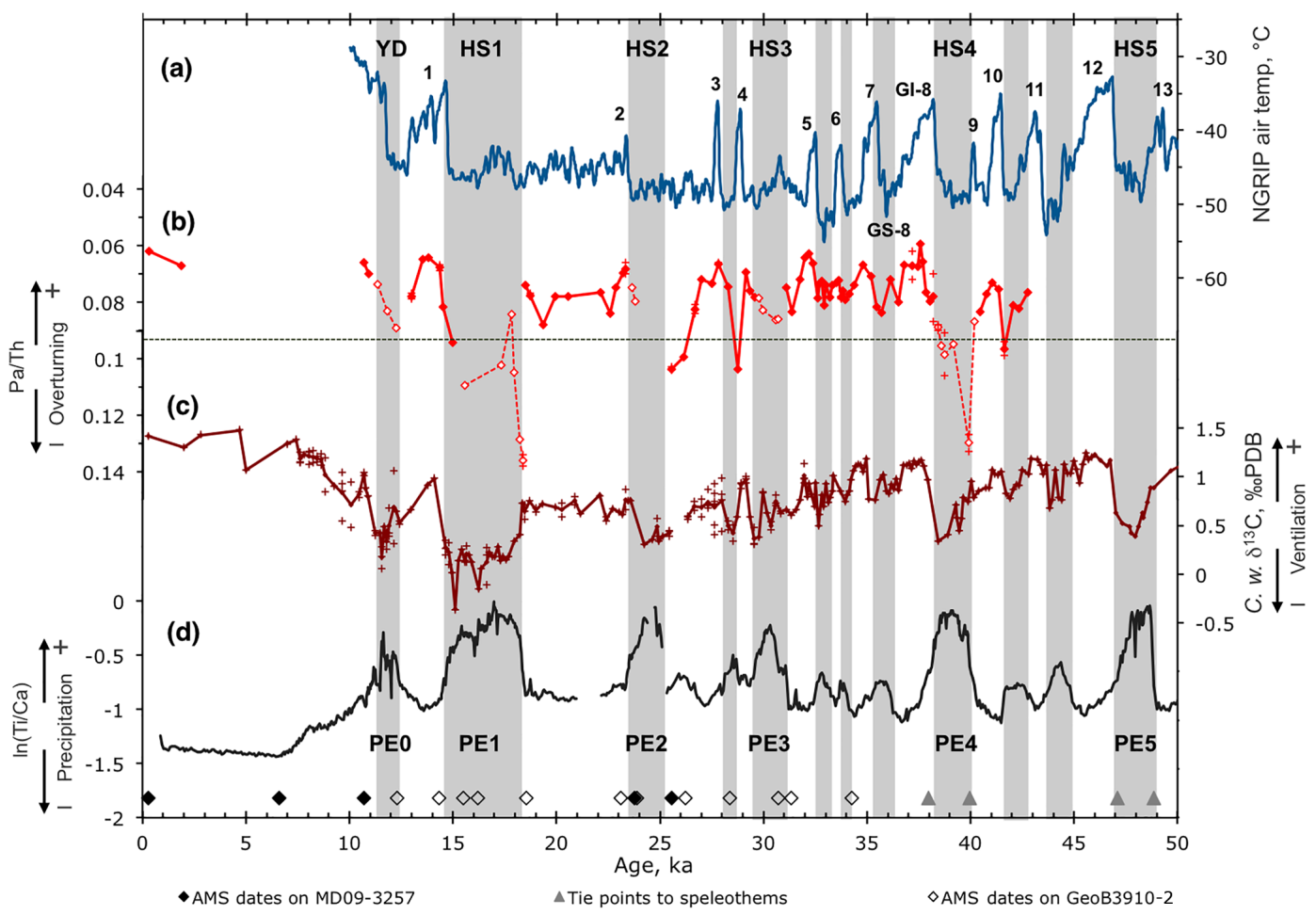

Figure 2. MD09-3257 Pa / Th, $\ln (\mathrm{Ti} / \mathrm{Ca})$ and composite $C$. wuellerstorfi $\delta^{13} \mathrm{C}\left(\delta^{13} \mathrm{C}_{\mathrm{Cw}}\right)$ records versus MD09-3257 age scale, independent from the North Greenland Ice Core Project (NGRIP) age scale. (a) NGRIP air temperature versus the Greenland Ice Core Chronology 2005 (GICC05) age scale (Kindler et al., 2014), transposed from kyr b2k (before 2000) to ka. Greenland interstadials are numbered according to Rasmussen et al. (2014). To avoid overcrowding the figure, Greenland stadials (GS) and interstadials (GI) are only explicitly named in the case of GS-8 and GI-8. (b) The MD09-3257 core Pa / Th record. Empty symbols denote data points that may be affected by terrigenous fluxes and should be interpreted with caution; crosses denote replicate measurements; the red line connects average values (filled symbols). $\mathrm{Pa} /$ Th could not be measured over the first half of PE2 because of the occurrence of two small sand layers (Burckel et al., 2015). (c) The MD09-3257 core and GeoB3910-2 core composite $\delta^{13} \mathrm{C}_{\mathrm{Cw}}$ record (Vazquez Riveiros et al., 2018); crosses denote replicate measurements. (d) MD09-3257 $\ln (\mathrm{Ti} / \mathrm{Ca}$ ). Diamonds above the $x$ axis indicate calibrated radiocarbon dates in MD09-3257 (filled symbols) and GeoB39102 (empty symbols). Triangles indicate alignment tie points to South American speleothem $\delta^{18} \mathrm{O}$ (Vazquez Riveiros et al., 2018). Grey bands delineate precipitation events recorded in $\mathrm{MD} 09-3257 \ln (\mathrm{Ti} / \mathrm{Ca})$.

well as temperature dependent air-sea exchanges (LynchStieglitz et al., 1995). DIC $\delta^{13} \mathrm{C}$ subsequently decreases as deep water ages, due to the progressive remineralization at depth of relatively ${ }^{13} \mathrm{C}$-depleted biogenic material. As a result, DIC $\delta^{13} \mathrm{C}$ largely follows water mass structure and circulation in the modern ocean, and C. wuellerstorfi $\delta^{13} \mathrm{C}$ $\left(\delta^{13} \mathrm{C}_{\mathrm{Cw}}\right.$ hereafter) has been used to trace water masses and as a proxy of bottom-water ventilation (Duplessy et al., 1988 and numerous subsequent studies). A recent study further highlighted that DIC $\delta^{13} \mathrm{C}$ more faithfully follows water oxygen content than phosphate content (Eide et al., 2017), lending strong support to the use of $\delta^{13} \mathrm{C}_{\mathrm{Cw}}$ as a proxy for bottom-water ventilation - the term ventilation here refers to the transmission of oxygen-rich, atmosphere-equilibrated water to the ocean interior.

\subsection{New sedimentary $\mathrm{Pa} /$ Th data}

New sedimentary $\left({ }^{231} \mathrm{~Pa}_{x s, 0} /{ }^{230} \mathrm{Th}_{x s, 0}\right)$ measurements (excess activity ratio at the time of deposition, $\mathrm{Pa} / \mathrm{Th}$ hereafter) were produced in core MD09-3257 in order to extend the $\mathrm{Pa} / \mathrm{Th}$ record of Burckel et al. (2015) and to cover the entire time interval from 10 to $43 \mathrm{ka}$ (Table S3). The excess activity corresponds to the fraction of each radioisotope produced in the water column by uranium (U) decay and is transferred to the sediment by adsorption onto particles sinking in the water column. ${ }^{230} \mathrm{Th}$ and ${ }^{231} \mathrm{~Pa}$ excess activities are calculated from bulk sediment measurement by correcting for the contribution of the detrital and authigenic fractions (François et al., 2004; Henderson and Anderson, 2003) using a detrital $\left({ }^{238} \mathrm{U} /{ }^{232} \mathrm{Th}\right.$ ) value of $0.5 \pm 0.1(2 \sigma)$ (Missiaen et al., 2018). These excess activities are then further corrected for radioactive decay since the time of sediment deposition. Bulk sediment measurements were performed by isotopic dilution mass spectrometry on the LSCE MC-ICP- 
MS (Neptune ${ }^{\text {Plus }}$, Thermo Fisher), following a method derived from Guihou et al. (2010). Error bars (2 standard deviations) on $\mathrm{Pa} / \mathrm{Th}$ measurements were computed by Monte Carlo runs (Missiaen et al., 2018), accounting for the uncertainties in $\mathrm{Pa}$, Th and $\mathrm{U}$ measurements, as well as those of the detrital $\left({ }^{238} \mathrm{U} /{ }^{232} \mathrm{Th}\right)$ value, spike calibrations and dating.

Sedimentary $\mathrm{Pa} / \mathrm{Th}$ can be used to reconstruct changes in the renewal rate of water masses overlying the core site. This tracer has been successfully used to reconstruct past changes in deep Atlantic circulation intensity (Burckel et al., 2015 and references therein). ${ }^{231} \mathrm{~Pa}$ and ${ }^{230} \mathrm{Th}$ are produced at a constant $\mathrm{Pa}$ / Th activity ratio of 0.093 by dissolved uranium, which is homogeneously distributed in oceans. ${ }^{230} \mathrm{Th}$ is much more particle reactive than ${ }^{231} \mathrm{~Pa}$, as reflected by their respective residence time in the ocean $\left(30-40 \mathrm{yr}\right.$ for ${ }^{230} \mathrm{Th}$ and 100 $200 \mathrm{yr}$ for ${ }^{231} \mathrm{~Pa}$, François, 2007). Therefore, ${ }^{230} \mathrm{Th}$ is rapidly removed from the water column to the underlying sediment, while ${ }^{231} \mathrm{~Pa}$ can be advected by oceanic currents. Thus, when averaged over an entire ocean basin, high (low) flow rates result in high (low) ${ }^{231} \mathrm{~Pa}$ export and a low (high) sedimentary $\mathrm{Pa} / \mathrm{Th}$ ratio. In contrast to $\delta^{13} \mathrm{C}_{\mathrm{CW}}$, which records the DIC $\delta^{13} \mathrm{C}$ of bottom waters at the core site, sedimentary $\mathrm{Pa} / \mathrm{Th}$ does not reflect the flow rate at the seabed but that of a water layer of a few hundreds to more than $1000 \mathrm{~m}$ above the seafloor (Thomas et al., 2006).

Several potential caveats of the proxy were tested. In particular, ${ }^{231} \mathrm{~Pa}$ has a higher affinity for opal than for the other types of particles (Chase et al., 2002), meaning that high opal fluxes can result in high sedimentary $\mathrm{Pa} / \mathrm{Th}$ values even in the presence of lateral advection. Similarly, areas of very high vertical particle flux, such as the Atlantic off western Africa, are characterized by high $\mathrm{Pa} / \mathrm{Th}$ values (Yu et al., 1996; François, 2007; Lippold et al., 2012). Recent studies have shown that the caveats that may apply to this proxy in some areas do not apply to the western tropical Atlantic region. More specifically, a study including core top material from the western tropical Atlantic margin and using a 2-D model (Luo et al., 2010) showed that the measured $\mathrm{Pa} / \mathrm{Th}$ vertical profile is consistent with a dominant role of the overturning circulation, rather than particle scavenging; this demonstrates that $\mathrm{Pa} / \mathrm{Th}$ can be used to record changes in water mass overturning rates in that region (Lippold et al., 2011). However, because there are large increases in terrigenous material deposition on the northeastern Brazilian margin during the last glacial, we carefully evaluated/assessed if increased terrigenous deposition may have impacted $\mathrm{Pa} / \mathrm{Th}$ values.

The ${ }^{230} \mathrm{Th}$-normalized ${ }^{232} \mathrm{Th}$ flux, hereafter simply referred to as the ${ }^{232} \mathrm{Th}$ flux, is indicative of the vertical terrigenous flux to the core site. As ${ }^{232} \mathrm{Th}$ is a trace element that is mostly contained in the continental crust (Taylor and McLennan, 1985), it is commonly used as a geochemical tracer for material of detrital origin (e.g., Anderson et al., 2006). Besides the main precipitation events PE0 to PE4, there is no significant correlation between the $\mathrm{Pa} / \mathrm{Th}$ ratio and the
${ }^{232}$ Th flux $(r=0.21, p=0.07)$ (Figs. S2 and S3). In contrast, because the correlation between $\mathrm{Pa} / \mathrm{Th}$ and the ${ }^{232} \mathrm{Th}$ flux becomes significant $(r=0.57, p \ll 0.001)$ when including the main precipitation events (Fig. S3), the high $\mathrm{Pa} / \mathrm{Th}$ values observed during PE0 to PE4 could be partly caused by increased terrigenous flux and should be interpreted with caution (empty symbols in Fig. 2). Note that a possible terrigenous influence during the main precipitation events does not preclude that the high $\mathrm{Pa} / \mathrm{Th}$ values during these periods reflect an almost halted oceanic circulation above the core site. Indeed, Pa scavenging by boundary scavenging can be intensified in times of reduced overturning circulation due to boundary scavenging becoming the main control on sedimentary $\mathrm{Pa} / \mathrm{Th}$.

Another source of possible biases in $\mathrm{Pa} / \mathrm{Th}$ results from variations in opal flux (Chase et al., 2002). However, the northern Brazilian margin is known for its low siliceous primary production (Arz et al., 1998). This is confirmed by ${ }^{230}$ Th-normalized opal flux measurements in MD09-3257, which are below $0.06 \mathrm{~g} \mathrm{~cm}^{-2} \mathrm{kyr}^{-1}$ (Fig. S3). Moreover, outside of precipitation events PE0 to PE4, there is no correlation between $\mathrm{Pa} / \mathrm{Th}$ and opal flux (Fig. S3). In conclusion, we may consider that outside of the main precipitation events, our $\mathrm{Pa} / \mathrm{Th}$ record can be interpreted in terms of changes in the strength of overturning circulation above the MD09-3257 coring site.

\subsection{Cross-correlation and wavelet analysis}

Assuming that there is a constant phase shift between two time series over their entire length, one can perform a simple cross-correlation analysis and compute how the correlation coefficient between the two time series varies as a function of the time lag between the two series (e.g., Davis, 1986).

We normalized (i.e., subtracted the mean and divided by the standard deviation) and resampled the time series $\mathrm{Pa} / \mathrm{Th}$, $\delta^{13} \mathrm{C}_{\mathrm{Cw}}$ and $\ln (\mathrm{Ti} / \mathrm{Ca})$ to a common age scale using scenarios with constant time steps varying between 50 and $500 \mathrm{yr}$. We then used the $R$ function cor.test (R package stats version 3.2.2) for correlation between paired series (R script in Supplement) to compute the Spearman correlation coefficient between all pairs of the three time series, after having shifted one with respect to the other by increments of the time step.

Another approach consists of classical spectral analysis methods that examine the coherence and phase between two time series in frequency space, such as Fourier transforms. Fourier transforms involve decomposing a signal into infinite-length oscillatory functions (such as sine waves). As such, these methods also rely on the assumption that the decomposition of each signal into characteristic frequencies is valid over its entire length, i.e., that the underlying processes are stationary in time.

In contrast, wavelet analysis can be used to decompose a time series into "time-frequency" space, rather than fre- 
quency space, that is, to determine both the dominant modes of variability and how these modes vary in time (Torrence and Compo, 1998). To do so, the wavelet transform decomposes the signal into a sum of small wave functions of finite length that are highly localized in time. Thus, wavelet transform can describe changes in frequencies along the studied time series and are particularly relevant for dealing with climatic signals, since they are in essence not stationary in time, but in constant evolution in response to external forcing (i.e., insolation changes), and as a result of internal climate variability.

Given two times series $X$ and $Y$, with wavelet transforms $W^{X}$ and $W^{Y}$, the cross-wavelet spectrum is defined as $W^{X Y}=W^{X} W^{Y *}$, where $W^{Y *}$ is the complex conjugate of $W^{Y}$ (Torrence and Compo, 1998). Similarly to Fourier coherency, which is used to identify frequency bands in which two time series are related, the wavelet coherency was developed to identify both frequency bands and time intervals over which the two time series are related. The wavelet coherence between two time series is defined as the square of the smoothed cross-wavelet spectrum normalized by the smoothed individual wavelet power spectra (Torrence and Webster, 1999). This definition resembles that of a traditional correlation coefficient, i.e., wavelet coherence ranges between 0 and 1, and may be viewed as a localized correlation coefficient in time-frequency space (Grinsted et al., 2004).

Analogous to Fourier cross-spectral analysis, the phase difference between two time series can also be computed using a cross-wavelet spectrum. The complex argument $\arg \left(W^{X Y}\right)$ can be interpreted as the local relative phase between $X$ and $Y$ in time-frequency space (Grinsted et al., 2004).

In the present study we use the software developed by Grinsted et al. (2004) to compute the cross-wavelet spectrum, coherence and relative phase between our time series that were normalized and resampled as previously described. To test for the persistence of regions of high cross-wavelet coherence, we ran all cross-wavelet analyses 1000 times for each dataset pair (i.e., a Monte Carlo approach). For each of the 1000 runs, each time data point was randomly sampled, whereby a Gaussian distribution of each data point's value (based on the measurement uncertainty) was used to weight the random sampling. Mean and standard deviation values for the coherence and phase direction were calculated using the 1000 runs.

\section{Results}

\subsection{Ocean circulation proxy records}

The Pa / Th record of core MD09-3257 now covers the entire 10-43 ka time interval, encompassing the Younger Dryas (YD) and the last four Heinrich stadials (Fig. 2). We have increased its temporal resolution over the time interval from
31 to 38 ka comprising Dansgaard-Oeschger (D-O) events 5 to 8 , with respect to the rest of the study period, in order to examine Atlantic circulation dynamics during D-O events.

$\mathrm{Pa} / \mathrm{Th}$ data exhibit systematic increases in conjunction with stadials, even if $\mathrm{Pa} / \mathrm{Th}$ data points that are potentially biased towards elevated values by increased terrigenous input (empty symbols) are discarded. Thus, $\mathrm{Pa} / \mathrm{Th}$ data indicate that the renewal rate of the water mass overlying the site decreased during stadials. More specifically, transport of the overlying water mass decreased not only during the YD and Heinrich stadials, but also during practically all D$\mathrm{O}$ stadials. Among $\mathrm{D}-\mathrm{O}$ stadials, the $\mathrm{Pa} / \mathrm{Th}$ increase is well marked for GS-7, GS-8 and GS-11, but the signal is too noisy to provide a clear picture for GS-6. This noisy $\mathrm{Pa} / \mathrm{Th}$ signal is very likely due to sediment reworking, given that the $\delta^{13} \mathrm{C}_{\mathrm{Cw}}$ record is also noisy over this section of the core. Also, it is noteworthy that no precipitation event is recorded in MD09-3257 or GeoB3910-2 during GS-10 (Fig. 2). There is no clear decrease in the well-dated El Condor (Cheng et al., 2013) speleothem $\delta^{18} \mathrm{O}$ records associated with GS-10 either, which is in contrast with the other Greenland stadials (Burckel et al., 2015). It would seem that there was no apparent increase in precipitation during GS-10 over tropical South America, in contrast with all other GS of the past $40 \mathrm{kyr}$. Overall, longer stadials seem to be associated with larger increases in $\mathrm{Pa} / \mathrm{Th}$ than shorter stadials.

The $\delta^{13} \mathrm{C}_{\mathrm{Cw}}$ composite record varies in concert with $\mathrm{Pa} / \mathrm{Th}$, with high values indicating the presence of wellventilated waters during the Holocene and interstadials, and low values indicating a marked reduction in water ventilation during stadials at $\sim 2350 \mathrm{~m}$ in the western equatorial Atlantic (Vazquez Riveiros et al., 2018).

\subsection{Relative timing of $\mathrm{Pa} / \mathrm{Th}, \delta^{13} \mathrm{C}_{\mathrm{Cw}}$ and $\mathrm{Ti} / \mathrm{Ca}$}

$\mathrm{Pa} / \mathrm{Th}, \delta^{13} \mathrm{C}_{\mathrm{Cw}}$ and $\mathrm{Ti} / \mathrm{Ca}$ are recorded in the same core or in two cores from the same location, which could be precisely aligned through high resolution XRF signals. This situation provides ideal conditions to examine the relative phasing of one proxy with respect to another. $\mathrm{Pa} / \mathrm{Th}$ and $\mathrm{Ti} / \mathrm{Ca}$ are recorded in the same core, so their relative phasing can consequently be examined with the smallest possible relative dating uncertainty, whereby the only remaining source of uncertainty is bioturbation. The situation is practically the same when examining $\delta^{13} \mathrm{C}_{\mathrm{Cw}}$ versus $\mathrm{Ti} / \mathrm{Ca}$ or $\delta^{13} \mathrm{C}_{\mathrm{Cw}}$ versus $\mathrm{Pa} / \mathrm{Th}$. Apart from the unavoidable uncertainty introduced by bioturbation, the relative dating uncertainty between the $\delta^{13} \mathrm{C}_{\mathrm{Cw}}$ composite record and any MD09-3257 record is null over 0-32 ka, and amounts to $102 \mathrm{yr}$ on average over the 32 50 ka time interval (Fig. S1).

In what follows, we assess the relative phasing between $\mathrm{Pa} / \mathrm{Th}, \delta^{13} \mathrm{C}_{\mathrm{Cw}}$ and $\mathrm{Ti} / \mathrm{Ca}$, using all $\mathrm{Pa} / \mathrm{Th}$ data points (including $\mathrm{Pa} / \mathrm{Th}$ values susceptible to being partially impacted by large particle fluxes or boundary scavenging resulting from slower overturning circulation) in order to have 


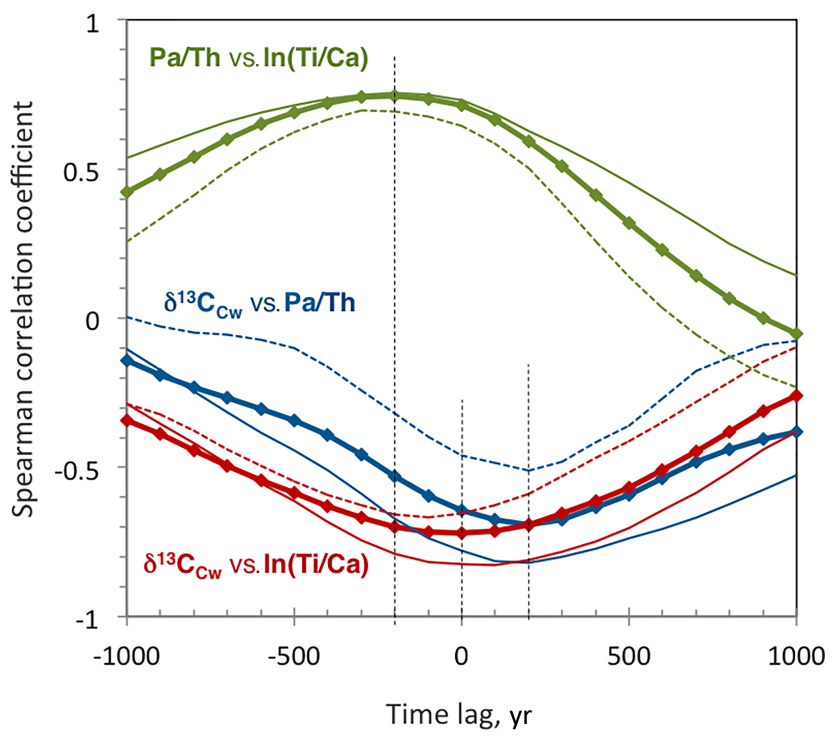

Figure 3. Spearman correlation coefficient of $\delta^{13} \mathrm{C}_{\mathrm{Cw}}$ versus $\mathrm{Pa} / \mathrm{Th}$ (blue curves), of $\delta^{13} \mathrm{C}_{\mathrm{Cw}}$ versus $\ln (\mathrm{Ti} / \mathrm{Ca}$ ) (red curves), and of $\mathrm{Pa} / \mathrm{Th}$ versus $\ln (\mathrm{Ti} / \mathrm{Ca}$ ) (green curves), as a function of the time lag. A positive time lag means that series 1 lags series 2 (e.g., $\delta^{13} \mathrm{C}_{\mathrm{Cw}}$ lags $\left.\mathrm{Pa} / \mathrm{Th}\right)$; a negative time lag means that series 1 leads series 2 (e.g., $\mathrm{Pa} / \mathrm{Th}$ leads $\ln (\mathrm{Ti} / \mathrm{Ca})$ ). Bold lines correspond to the calculation over the entire time interval from 10.6 to $42.6 \mathrm{ka}$, thin lines to the calculation over the time interval from 10.6 to $26.6 \mathrm{ka}$, and thin dashed lines to the calculation over the time interval from 26.6 to $42.6 \mathrm{ka}$. Vertical dashed lines indicate the time lags corresponding to the maximum correlation coefficients for the three pairs of series over the entire time interval.

sufficient data to examine periodicities ranging from 1000 to $6000 \mathrm{yr}$. In doing so, we assume that changes in particle fluxes may affect the amplitude of the $\mathrm{Pa} / \mathrm{Th}$ changes, rather than the timing of these changes. In the following text, we show that excluding the $\mathrm{Pa} / \mathrm{Th}$ values susceptible to being partially impacted by large particle fluxes does not change our conclusions concerning D-O periodicities (i.e., 1000 to $3000 \mathrm{yr})$.

\subsubsection{Average relative phases}

We first apply the simple stationary cross-correlation approach to examine how the correlation coefficients of $\mathrm{Pa} / \mathrm{Th}$ versus $\ln (\mathrm{Ti} / \mathrm{Ca})$, of $\delta^{13} \mathrm{C}_{\mathrm{Cw}}$ versus $\ln (\mathrm{Ti} / \mathrm{Ca})$, and of $\delta^{13} \mathrm{C}_{\mathrm{Cw}}$ versus $\mathrm{Pa} / \mathrm{Th}$, vary as a function of the lag between the different time series (Fig. 3). Prior to computing the correlation coefficients, the three time series were resampled with a time step of $100 \mathrm{yr}$ and normalized.

Taken at face value, these results indicate that $\mathrm{Pa} / \mathrm{Th}$ leads $\ln (\mathrm{Ti} / \mathrm{Ca}$ ) (or Ti / Ca) by $200 \pm 100 \mathrm{yr}$, that there is no significant phase shift between $\delta^{13} \mathrm{C}_{\mathrm{Cw}}$ and $\mathrm{Ti} / \mathrm{Ca}$, and that $\delta^{13} \mathrm{C}_{\mathrm{Cw}}$ lags Pa / Th by $200 \pm 100 \mathrm{yr}$ (Table S4). The uncertainty of $\pm 100 \mathrm{yr}$ directly results from the adopted sampling step of $100 \mathrm{yr}$. In addition, in order to assess the robustness of these results, we applied the same approach to the upper half and lower half of the records. In all cases, we obtained $\delta^{13} \mathrm{C}_{\mathrm{Cw}}$ lags over $\mathrm{Pa} / \mathrm{Th}$ of $200 \mathrm{yr}$, and $\mathrm{Pa} / \mathrm{Th}$ leads over $\ln (\mathrm{Ti} / \mathrm{Ca})$ of 200 or $300 \mathrm{yr}$, while the phase shift between $\delta^{13} \mathrm{C}_{\mathrm{Cw}}$ and $\mathrm{Ti} / \mathrm{Ca}$ remained between -100 and $+100 \mathrm{yr}$.

Although this simple method has been applied to climatic time series in previous studies (Langehaug et al., 2016; Henry et al., 2016), such results must be interpreted with caution, as the method has been designed for signals that are stationary in time and is therefore not suitable for climatic signals.

\subsubsection{Wavelet transforms}

The non-stationary character of climatic signals over the last $40-45 \mathrm{kyr}$ is particularly pronounced. Different typical pseudo-periodicities can be identified for Heinrich and DO stadials. In the case of Heinrich stadials (corresponding to our main precipitation events), the interval from 11.7 to $49 \mathrm{ka}$ comprises five pseudo-cycles that are $\sim 6$ to $9 \mathrm{kyr}$ long (Fig. 2), such that Heinrich stadials over the studied interval are characterized by an average pseudo-periodicity of about 7 kyr. Concerning D-O events, the interval located between HS3 and HS4 (32.5-38.1 ka) comprises three pseudo-cycles that are $\sim 1.2,1.5$ and $3 \mathrm{kyr}$ long (Fig. 2), yielding an average pseudo-periodicity of about $1.8 \mathrm{kyr}$.

We computed the cross-wavelet spectrum, coherence and phase between $\ln (\mathrm{Ti} / \mathrm{Ca}$ ) and $\mathrm{Pa} / \mathrm{Th}$ (Fig. 4), between $\delta^{13} \mathrm{C}_{\mathrm{Cw}}$ and $\mathrm{Pa} / \mathrm{Th}$ (Fig. 5), and between $\delta^{13} \mathrm{C}_{\mathrm{Cw}}$ and $\ln (\mathrm{Ti} / \mathrm{Ca})$ (Fig. 6), using the software from Grinsted et al. (2004). The $95 \%$ confidence level against red noise is shown as a thick contour line. Relative phases are only plotted for coherences higher than $0.5(<0.5$ is masked as dark blue). Note that the shaded areas in Figs. 4-6 correspond to the region of the wavelet transform graphs where the edge effects due to the finite length of the time series limit the ability to carry out cross-wavelet analysis. These regions are not considered in our interpretations.

To assess the robustness of our results, we repeated the cross-wavelet transform for different interpolation resolutions ranging from 50 to $500 \mathrm{yr}$; therefore, we could verify that the features corresponding to the $95 \%$ confidence level against red noise for a time step of $100 \mathrm{yr}$ are still present at roughly the same time and frequency for other time steps (e.g., see Fig. S4 for results obtained for a time step of $400 \mathrm{yr})$.

Moreover, we ran a spectrogram analysis in order to confirm our wavelet results and avoid any overinterpretation (see Fig. S5 and explicative caption). Unlike the wavelet, the spectrogram analysis is based on a finite time Fourier transform that spans different periods. Therefore, it provides an alternative base to check wavelet-based results. These tests confirmed the wavelet results for periods between 1 and $6 \mathrm{kyr}$. Beyond $6 \mathrm{kyr}$, wavelet results could not be confirmed by spectrograms due to the short duration of the analyzed 

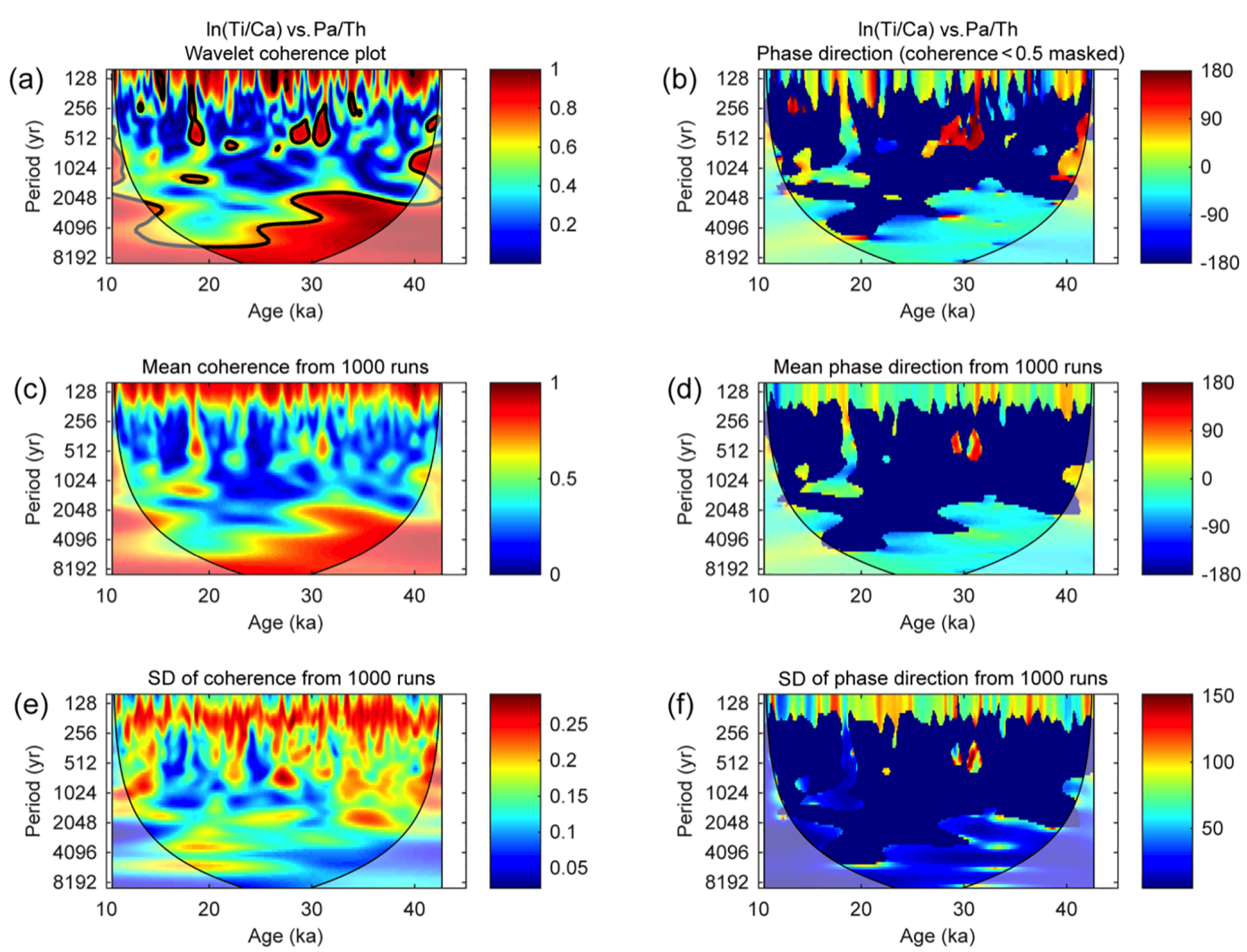

Figure 4. Cross-wavelet transform of MD09-3257 $\ln (\mathrm{Ti} / \mathrm{Ca})$ versus $\mathrm{Pa} / \mathrm{Th}$. (a, b) Wavelet coherence and phase direction computed using Grinsted et al. (2004) software. The thick contour line corresponds to the $95 \%$ confidence level against red noise. Phase direction is only computed for coherences higher than 0.5. (c, d) Mean coherence and phase direction computed from 1000 Monte Carlo simulations. (e, f) Standard deviation around the mean coherence and phase direction computed from these 1000 Monte Carlo simulations.

Table 1. Relative phases over regions of the cross-wavelet graphs corresponding to coherences $>0.5$.

\begin{tabular}{|c|c|c|c|c|c|c|c|c|}
\hline & $\begin{array}{l}\text { Time } \\
\text { interval }\end{array}$ & $\begin{array}{l}\text { Period } \\
\text { range }\end{array}$ & $\begin{array}{l}\text { Perio- } \\
\text { dicity }\end{array}$ & $\begin{array}{r}\text { Phase } \\
\left({ }^{\circ}\right)\end{array}$ & $\begin{array}{l}1 \sigma \\
\left(^{\circ}\right)\end{array}$ & $\begin{array}{r}\text { Phase } \\
(\mathrm{yr})\end{array}$ & $\begin{array}{r}1 \sigma \\
(\mathrm{yr})\end{array}$ & Comment \\
\hline \multirow[t]{2}{*}{$\ln (\mathrm{Ti} / \mathrm{Ca})$ vs. Pa / Th (Fig. 4) } & $28-40 \mathrm{ka}^{*}$ & $1000-3000$ & 2000 & -46.7 & 25.2 & -259 & 140 & $\mathrm{~Pa} / \mathrm{Th}$ leads $\ln (\mathrm{Ti} / \mathrm{Ca})$ \\
\hline & $15-40 \mathrm{ka}^{*}$ & $4000-6000$ & 5000 & -45.4 & 24.8 & -631 & 345 & $\mathrm{~Pa} / \mathrm{Th}$ leads $\ln (\mathrm{Ti} / \mathrm{Ca})$ \\
\hline \multirow[t]{2}{*}{$\delta^{13} \mathrm{C}_{\mathrm{Cw}}$ vs. Pa / Th (Fig. 5) } & $28-40 \mathrm{ka}$ & $1000-3000$ & 2000 & -50.2 & 39.7 & -279 & 244 & $\mathrm{~Pa} / \mathrm{Th}$ leads $\delta^{13} \mathrm{C}_{\mathrm{Cw}}$ \\
\hline & $15-40 \mathrm{ka}$ & $4000-6000$ & 5000 & -14.1 & 37.1 & -196 & 525 & Not significant \\
\hline \multirow[t]{2}{*}{$\delta^{13} \mathrm{C}_{\mathrm{Cw}}$ vs. $\ln (\mathrm{Ti} / \mathrm{Ca})$ (Fig. 6) } & $28-40 \mathrm{ka}$ & $1000-3000$ & 2000 & 17 & 24.3 & 94 & 171 & Not significant \\
\hline & $15-40 \mathrm{ka}$ & $4000-6000$ & 5000 & 10.8 & 42.9 & 150 & 606 & Not significant \\
\hline
\end{tabular}

* Within these time intervals, only results from the unshaded region of the wavelet graphs are taken into account.

records. Thus, we do not discuss periodicities longer than $6 \mathrm{kyr}$ in what follows.

With this in mind, the following regions of significant mean coherence and well-defined mean relative phases can be identified in the cross-wavelet graphs between $\mathrm{Pa} / \mathrm{Th}$ and $\ln (\mathrm{Ti} / \mathrm{Ca}$ ) produced by 1000 Monte Carlo runs (Fig. 4, middle panels): a coherence higher than 0.5 is found for periodicities around $2000 \mathrm{yr}$ (ranging from $\sim 1000$ to $3000 \mathrm{yr}$ ) over the time interval from $\sim 28$ to $40 \mathrm{ka}$, and for periodicities around $5000 \mathrm{yr}(\sim 4000$ to $6000 \mathrm{yr})$ over $\sim 25-40 \mathrm{ka}$. Com- puting the average phases over each of these two regions, we find that $\mathrm{Pa} / \mathrm{Th}$ leads $\ln (\mathrm{Ti} / \mathrm{Ca})$ by $259 \pm 140 \mathrm{yr}(1 \sigma)$ for periodicities of 1000 to $3000 \mathrm{yr}$ over $28-40 \mathrm{ka}$, and by $631 \pm 345 \mathrm{yr}(1 \sigma)$ for periodicities of 4000 to $6000 \mathrm{yr}$ over 15-40 ka (Table 1).

The cross-wavelet graph between $\delta^{13} \mathrm{C}_{\mathrm{Cw}}$ and $\mathrm{Pa} / \mathrm{Th}$ displays slightly different regions of high mean coherence (Fig. 5, middle panels). Examining the same frequency bands as for $\mathrm{Pa} / \mathrm{Th}$ versus $\ln (\mathrm{Ti} / \mathrm{Ca}$ ), we find mean coherences higher than 0.5 for periodicities around $2000 \mathrm{yr}$ over $\sim 28$ 
$40 \mathrm{ka}$, and for periodicities around $5000 \mathrm{yr}$ over $\sim 15-40 \mathrm{ka}$. Average phases for these regions indicate that $\delta^{13} \mathrm{C}_{\mathrm{Cw}}$ lags $\mathrm{Pa} / \mathrm{Th}$ by $279 \pm 244 \mathrm{yr}(1 \sigma)$ for periodicities of 1000 to $3000 \mathrm{yr}$ over $28-40 \mathrm{ka}$, but that the lag of $\delta^{13} \mathrm{C}_{\mathrm{Cw}}$ with respect to $\mathrm{Pa} / \mathrm{Th}$ for periodicities of 4000 to $6000 \mathrm{yr}$ over $\sim 15-40 \mathrm{ka}$ is not significant (Table 1).

Finally, the regions characterized by mean coherences higher than 0.5 between $\delta^{13} \mathrm{C}_{\mathrm{Cw}}$ and $\ln (\mathrm{Ti} / \mathrm{Ca})$ are similar to those observed in the graph for $\mathrm{Pa} / \mathrm{Th}$ and $\ln (\mathrm{Ti} / \mathrm{Ca})$ (Fig. 6, middle panels). However, the average phases between $\delta^{13} \mathrm{C}_{\mathrm{Cw}}$ and $\ln (\mathrm{Ti} / \mathrm{Ca})$ over these regions are not significantly different from zero (Fig. 6d and Table 1), indicating that decreases in $\delta^{13} \mathrm{C}_{\mathrm{Cw}}$ are in phase with increases in $\ln (\mathrm{Ti} / \mathrm{Ca})$ within uncertainties.

The uncertainties of the leads and lags (Table 1) are computed assuming Gaussian error propagation of the two following independent uncertainties: (i) the standard deviation of the mean relative phases over the given time-frequency region (Figs. 4-6d), and (ii) the median value of the standard deviation computed by 1000 Monte Carlo runs over the same time-frequency region (Figs. 4-6f). In the case of relative phases between $\mathrm{Pa} / \mathrm{Th}$ or $\ln (\mathrm{Ti} / \mathrm{Ca})$ and $\delta^{13} \mathrm{C}_{\mathrm{Cw}}$, we also accounted for the additional error due to the combining of the MD09-3257 and GeoB3910-2 $\delta^{13} \mathrm{C}_{\mathrm{Cw}}$ records.

Finally, we applied the aforementioned cross-wavelet method to the subset of $\mathrm{Pa} / \mathrm{Th}$ data points not affected by large particle fluxes. For the periodicities between $\sim 1000$ and $4000 \mathrm{yr}$, the results obtained using this subset (Fig. S6) are virtually unchanged with respect to the results obtained using the entire dataset. For longer periodicities, coherence decreases as expected because the suppressed data points are all located in the main precipitation events (i.e., the YD and Heinrich stadials).

\section{Discussion}

\subsection{Reconstructed ocean circulation changes over the last $45 \mathrm{kyr}$}

Oceanographic studies have shown that the southward transport of northern-sourced waters in the equatorial Atlantic mainly takes place between a depth of $\sim 1300$ and $4000 \mathrm{~m}$ in $\mathrm{a} \sim 100 \mathrm{~km}$ wide Deep Western Boundary Current (DWBC) (Lux et al., 2001; Rhein et al., 2015). Using hydrographic, geochemical and direct velocity measurements acquired in 1993 to inverse an ocean circulation model, Lux et al. (2001) estimated that the volumetric flow of upper NADW occupying water depths between $\sim 1300$ and $2300 \mathrm{~m}$ at $4.5^{\circ} \mathrm{S}$ within the DWBC is $11.2 \mathrm{~Sv}\left(1 \mathrm{~Sv}=10^{6} \mathrm{~m}^{3} \mathrm{~s}^{-1}\right)$. This estimate is in good agreement with the $10.9 \mathrm{~Sv}$ estimated by Schott et al. (2003) based on data from 13 shipboard currentprofiling sections taken during the World Ocean Circulation Experiment period (1990-2002).

Our data show that outside of the main precipitation events, the total vertical particle flux did not vary much (re- maining within $25.1 \pm 3.6 \mathrm{~g} \mathrm{~m}^{-2} \mathrm{yr}^{-1}, 1 \sigma$ ) (Fig. S2). The $\mathrm{Pa} / \mathrm{Th}$ values of these interstadials are similar or slightly higher than those of the late Holocene (Fig. 2), suggesting that the transport of the water mass overlying the MD093257 core site was also $\sim 10 \mathrm{~Sv}$ during these interstadials.

It is more difficult to translate the observed increases in $\mathrm{Pa} / \mathrm{Th}$ during stadials into quantified decreases in water mass transport. However, our new data bring additional observational constraints on the Atlantic circulation changes associated with last glacial millennial climate changes. Two recent studies have indicated that decreases in northernsourced deep water flow took place during each stadial. On the one hand, increases in $\mathrm{Pa} / \mathrm{Th}$ during each stadial of the last glacial have been observed at a very deep western North Atlantic site located at $\sim 42^{\circ} \mathrm{N}$ and a depth of $4500 \mathrm{~m}$ (Henry et al., 2016). On the other hand, reconstructions of water corrosiveness in a South Atlantic core located at $\sim 44^{\circ} \mathrm{S}$ and a depth of $3800 \mathrm{~m}$ indicate the absence of northern-sourced deep water at that site during stadials, whereas nearly all interstadials of the last $60 \mathrm{kyr}$ are characterized by incursions of northern-sourced deep water into the deep South Atlantic (Gottschalk et al., 2015). Together with these independent results, our results indicate that decreases in both the flow rate and extension of northern-sourced deep waters during stadials were not limited to very dense waters circulating at $3800 \mathrm{~m}$ or deeper, but also affected water mass transport above $2350 \mathrm{~m}$ in the western equatorial Atlantic.

\subsection{Relative timing of $\mathrm{Pa} / \mathrm{Th}, \delta^{13} \mathrm{C}_{\mathrm{Cw}}$ and $\mathrm{Ti} / \mathrm{Ca}$}

\subsubsection{Stationary cross-correlation versus cross-wavelet results}

At the MD09-3257 site, cross-wavelet graphs (Figs. 4-6) show that significant coherence and well-defined relative phases between $\delta^{13} \mathrm{C}_{\mathrm{Cw}}, \mathrm{Pa} / \mathrm{Th}$ and $\mathrm{Ti} / \mathrm{Ca}$ can only be identified in some regions of the time-frequency space. For instance, when examining the relative phase between $\delta^{13} \mathrm{C}_{\mathrm{Cw}}$ and $\mathrm{Pa} / \mathrm{Th}$ over the interval from 10 to $43 \mathrm{ka}$, a meaningful relative phase can only be identified over $\sim 28-40 \mathrm{ka}$ at D-O frequencies (i.e., periodicities of 1000 to $3000 \mathrm{yr}$ ) (Fig. 5, Table 1). Furthermore, cross-wavelet results indicate that $\delta^{13} \mathrm{C}_{\mathrm{Cw}}$ lags $\mathrm{Pa} / \mathrm{Th}$ by $279 \pm 244$ yr at $\mathrm{D}-\mathrm{O}$ frequencies, and that decreases in $\delta{ }^{13} \mathrm{C}_{\mathrm{Cw}}$ are in phase with increases in $\mathrm{Pa} / \mathrm{Th}$ for periodicities of 4000 to $6000 \mathrm{yr}$ (i.e., closer to Heinrich periodicities). This is in contrast with the constant $200 \pm 100$ lag of $\delta^{13} \mathrm{C}_{\mathrm{Cw}}$ with respect to $\mathrm{Pa} / \mathrm{Th}$ obtained by cross-correlation between the two same time series (Fig. 3), and confirms that the latter method yields imprecise and unreliable results when applied to non-stationary climatic signals.

Nevertheless, cross-correlation has recently been applied to climatic signals (Langehaug et al., 2016), including $\mathrm{Pa} / \mathrm{Th}$ and $\delta^{13} \mathrm{C}_{\mathrm{Cw}}$ records from the last glacial (Henry et al., 2016). In the latter study, cross-correlation between ma- 

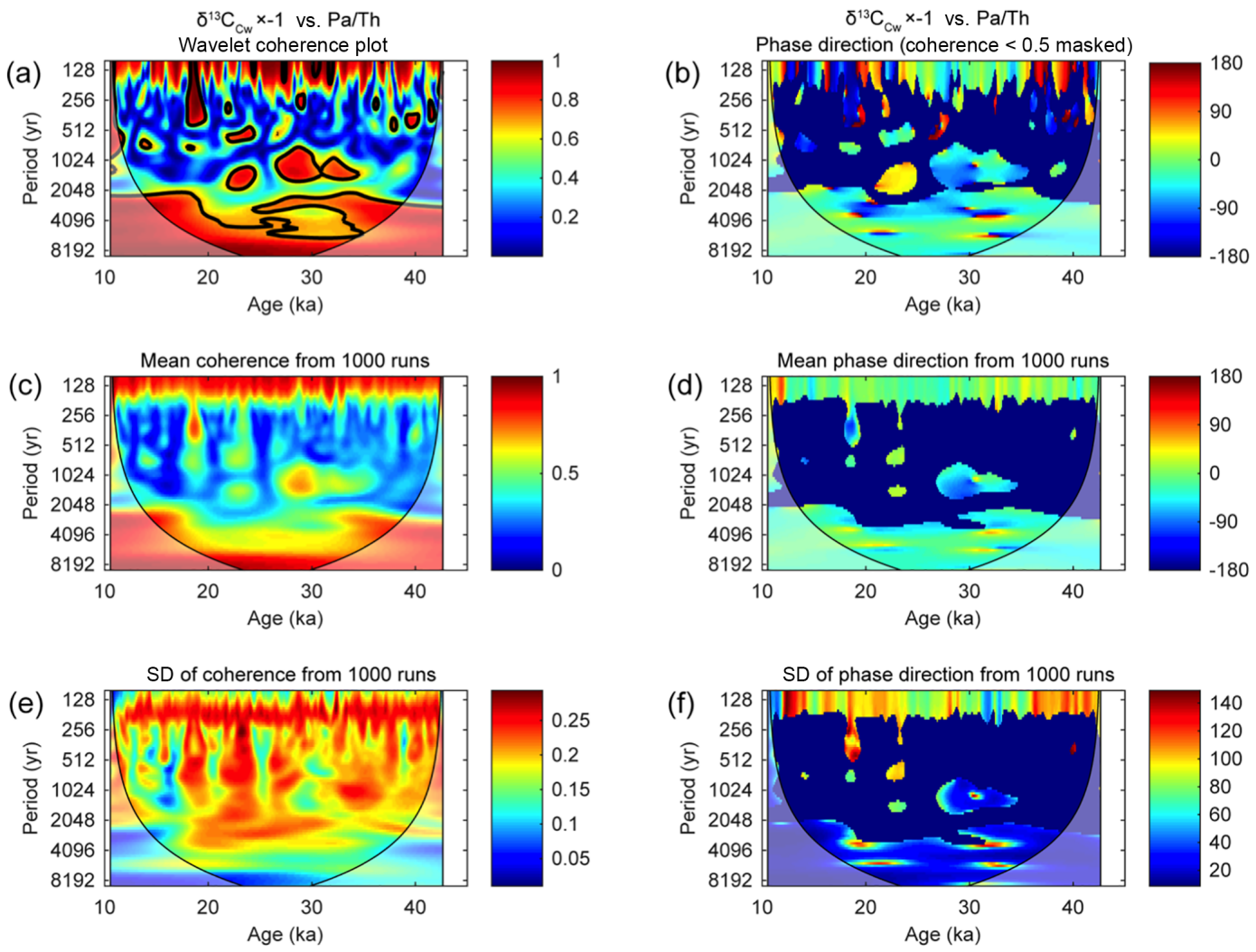

Figure 5. Cross-wavelet transform of $\delta^{13} \mathrm{C}_{\mathrm{Cw}}$ composite record versus MD09-3257 Pa / Th. $\delta^{13} \mathrm{C}_{\mathrm{Cw}}$ values have been multiplied by -1 to allow a straightforward reading of the relative phase between a decrease in $\delta^{13} \mathrm{C}$ and an increase in $\mathrm{Pa} / \mathrm{Th}$. (a)-(f) as in Fig. 4.

rine records from two deep Bermuda Rise cores and the NGRIP ice oxygen isotopic record was used to infer that deep Bermuda Rise $\delta^{13} \mathrm{C}_{\mathrm{Cw}}$ led NGRIP by approximately two centuries, and that $\mathrm{Pa} / \mathrm{Th}$ was approximately in phase with NGRIP over the interval from 25 to $60 \mathrm{ka}$ (Henry et al., 2016). The authors further inferred that $\mathrm{Pa} / \mathrm{Th} \operatorname{lags} \delta^{13} \mathrm{C}_{\mathrm{Cw}}$ by two centuries at their deep Bermuda Rise site. However, as shown here, cross-correlation is not a suitable method to analyze non-stationary climatic signals such as those of the last glacial. Moreover, the inferred relative phases between the marine and NGRIP records are much smaller than the dating error for each individual time series; therefore they are also much smaller than the relative dating error of one time series with respect to the other. In summary, the application of stationary cross-correlation techniques and incomplete consideration of geochronological uncertainty casts doubt on the conclusions of the aforementioned studies.

\subsubsection{Lead of $\mathrm{Pa} / \mathrm{Th}$ with respect to $\ln (\mathrm{Ti} / \mathrm{Ca})$}

Our cross-wavelet results show that MD09-3257 Pa/Th leads $\ln (\mathrm{Ti} / \mathrm{Ca})$ by $259 \pm 140 \mathrm{yr}(1 \sigma)$ for periods of 1000 to 3000 yr during the $\sim 28-40$ ka time interval, and by $631 \pm$ $345 \mathrm{yr}(1 \sigma)$ for periods of 4000 to $6000 \mathrm{yr}$ during $\sim 15-40 \mathrm{ka}$ (Table 1). Periods of 1000 to $3000 \mathrm{yr}$ correspond to pseudo- periodicities typical of D-O stadials, while periods of 4000 to $6000 \mathrm{yr}$ are close to those of Heinrich stadials. It can be noted that the cross-wavelet results for $\mathrm{D}-\mathrm{O}$ periodicities are only significant for the $\sim 28-40 \mathrm{ka}$ time interval, which indeed corresponds to the interval of our records for which D$\mathrm{O}$ events are best recorded.

It is important to examine if the observed relative phases could be an artifact due to bioturbation. It has been shown that smaller particles are more likely to be transported by bioturbation than larger particles (Wheatcroft, 1992; McCave, 1988; DeMaster and Cochran, 1982), and that this results in fine particles having apparent younger ages than coarse particles from the same depth in a core (Brown et al., 2001; Sepulcre et al., 2017).

Sedimentary $\mathrm{Pa} / \mathrm{Th}$ is measured on bulk sediment samples, with dissolved $\mathrm{Pa}$ and Th being more readily adsorbed on small particles because of their higher surface to volume ratio (Chase et al., 2002). It has been shown that 50\%-90\% of ${ }^{230} \mathrm{Th}$ excess inventory is found in particles smaller than $10 \mu \mathrm{m}$ (Kretschmer et al., 2010; Scholten et al., 1994; Thomson et al., 1993). Therefore, it is reasonable to assume that the $\mathrm{Pa} /$ Th signal is mostly carried by small particles $(<100 \mu \mathrm{m})$.

Assessing the size fraction corresponding to the $\mathrm{Ti} / \mathrm{Ca}$ signal is more complicated. XRF measurements show that the marked changes in $\ln (\mathrm{Ti} / \mathrm{Ca})$ recorded in MD09-3257 

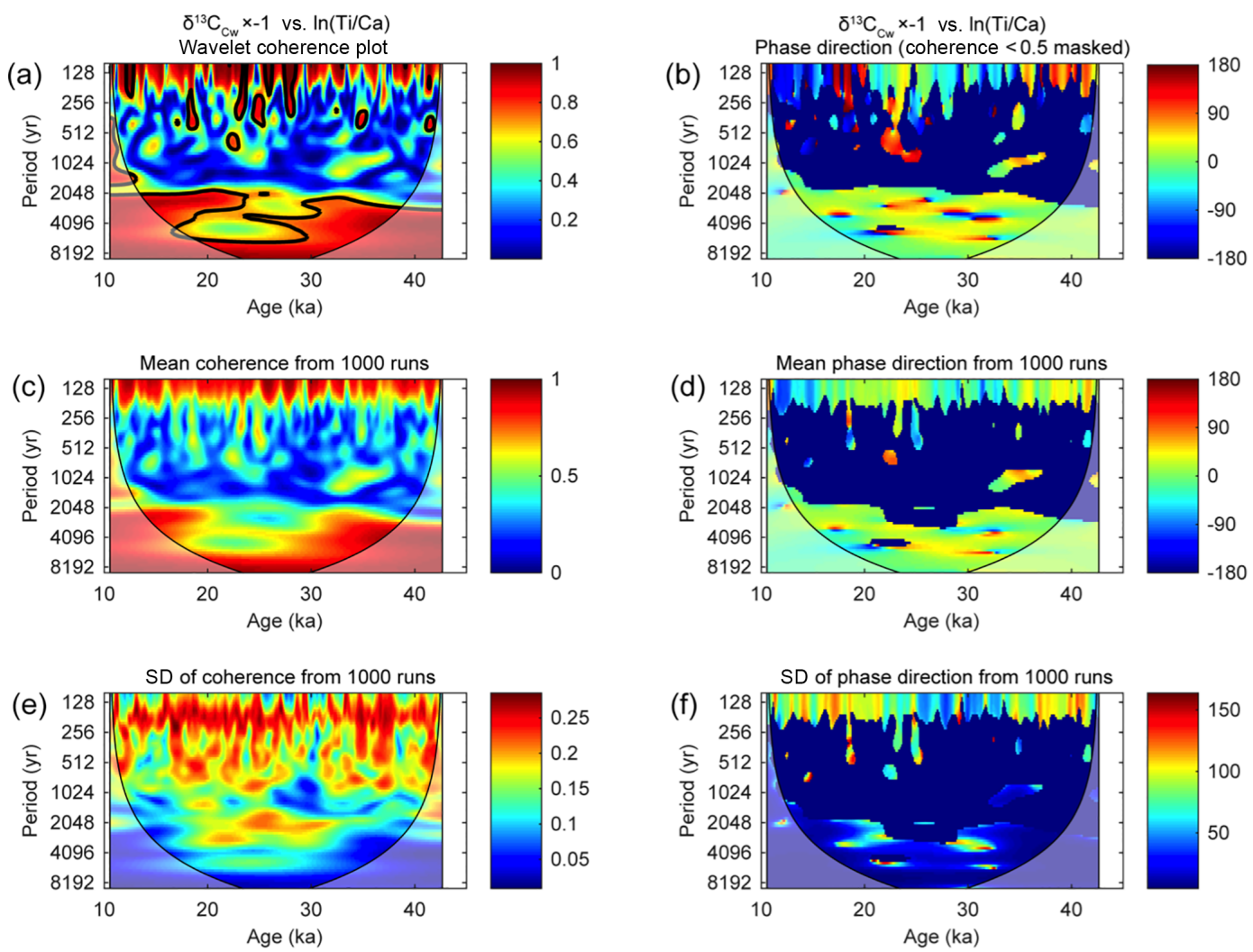

Figure 6. Cross-wavelet transform of $\delta^{13} \mathrm{C}_{\mathrm{Cw}}$ composite record versus MD09-3257 $\ln (\mathrm{Ti} / \mathrm{Ca}) . \delta^{13} \mathrm{C}_{\mathrm{Cw}}$ values have been multiplied by -1 to allow a straightforward reading of the relative phase between a decrease in $\delta^{13} \mathrm{C}$ and an increase in $\ln (\mathrm{Ti} / \mathrm{Ca})$. (a-f) as in Figs. 4 and 5.

result from sharp changes in both $\mathrm{Ca}$ and $\mathrm{Ti}$ concentration in the sediment. Ca is a component of marine calcite and aragonite, and is thus mainly carried by large size fractions of the sediment $(>60 \mu \mathrm{m})$. However, previous studies have shown that changes in marine carbonate production and dissolution between 2000 and $3000 \mathrm{~m}$ in the western tropical Atlantic were relatively small over the last glacial (Rühlemann et al., 1996; Gerhardt et al., 2000). Therefore, the sharp decreases in $\mathrm{Ca}$ concentration during stadials result from the dilution of marine carbonates by the increased input of terrigenous material. Therefore, the $\ln (\mathrm{Ti} / \mathrm{Ca})$ is driven by changes in terrigenous input, rather than changes in marine carbonate production or dissolution. It is difficult to assess in which particle size fraction $\mathrm{Ti}$ is mostly concentrated. Knowing that $\mathrm{Rb}$ and $\mathrm{K}$ are typical constituents of clays, and thus characteristic of small grain sizes, we verified if a phase shift could be detected between the XRF Ti signal and the XRF Rb and $\mathrm{K}$ signals. We found no relative offset between $\mathrm{Ti}$ and $\mathrm{Rb}$ and almost no relative offset between $\mathrm{Ti}$ and $\mathrm{K}$, with the inflexion point in the $\mathrm{K}$ signal taking place $0.05 \mathrm{~cm}$ deeper than in the Ti signal. Given that core MD09-3257 sedimentation rates range from 6 to $14 \mathrm{~cm} \mathrm{kyr}^{-1}, 0.05 \mathrm{~cm}$ corresponds to 5 to $10 \mathrm{yr}$; thus, it is completely negligible with respect to the observed phase shifts between $\ln (\mathrm{Ti} / \mathrm{Ca}$ ) and $\mathrm{Pa} / \mathrm{Th}$. Therefore, we may consider that $\ln (\mathrm{Ti} / \mathrm{Ca})$ and $\mathrm{Pa} / \mathrm{Th}$ are both carried by small particles and that the observed phase shifts between these two signals are not the result of bioturbation.

Finally, if, against all likelihood, bioturbation were responsible for a lead of $\mathrm{Pa} / \mathrm{Th}$ with respect to $\ln (\mathrm{Ti} / \mathrm{Ca})$, such a lead would be independent of the examined periodicity. Therefore, we may reasonably assume that the observed lead of $\mathrm{Pa} / \mathrm{Th}$ with respect to $\ln (\mathrm{Ti} / \mathrm{Ca})$ is not an artifact resulting from bioturbation.

We compute a $631 \pm 345 \mathrm{yr}(1 \sigma)$ lead for $\mathrm{Pa} / \mathrm{Th}$ over $\ln (\mathrm{Ti} / \mathrm{Ca})$ by cross-wavelet analysis for frequencies close to those characterizing Heinrich stadials. This lead is comparable to the relative phase previously estimated between

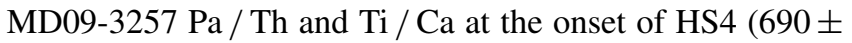
$180 \mathrm{yr})$ and HS2 $(1420 \pm 250 \mathrm{yr})$, respectively, based on the identification of the transition in the $\mathrm{Pa} / \mathrm{Th}$ and $\mathrm{Ti} / \mathrm{Ca}$ signals at the beginning of these two stadials (Burckel et al., 2015). The large lead of $\mathrm{Pa} / \mathrm{Th}$ with respect to $\ln (\mathrm{Ti} / \mathrm{Ca})$ is clearly visible for the YD and all Heinrich stadials, except HS1 (Fig. 2). The apparent synchronicity of the $\mathrm{Pa} / \mathrm{Th}$ and $\ln (\mathrm{Ti} / \mathrm{Ca})$ signals at the onset of HS1 in core MD09-3257, as also recently observed in another core from the northern Brazilian margin (Mulitza et al., 2017), suggests that the sequence of events was different at the beginning of HS1 from those at the beginning of the YD and other Heinrich stadials. Such a different sequence of events seems to indicate that 
the increase in rainfall over tropical South America during HS1 was not a response to a decrease in Atlantic overturning circulation. Instead, a southward shift of the low-latitude atmospheric convection zone (Intertropical Convergence Zone, ITCZ), along with its associated maximum in precipitation, could have occurred in response to extended Northern Hemisphere ice sheets and sea ice cover without any change in ocean circulation (Chiang et al., 2003). This atmospheric mechanism would have prevailed at the beginning of HS1 because ice sheets reached their maximum extent around that time.

Our results also indicate that a significant lead of $\mathrm{Pa} / \mathrm{Th}$ with respect to $\ln (\mathrm{Ti} / \mathrm{Ca})$ is present at $\mathrm{D}-\mathrm{O}$ frequencies. Moreover, the lead of $\mathrm{Pa} / \mathrm{Th}$ with respect to $\ln (\mathrm{Ti} / \mathrm{Ca})$ is markedly shorter at $\mathrm{D}-\mathrm{O}$ frequencies $(259 \pm 140 \mathrm{yr})$ than at Heinrich frequencies $(631 \pm 345 \mathrm{yr})$.

Climate models simulate a southward shift of the ITCZ in response to a slowdown of the Atlantic meridional overturning circulation (AMOC), but after just a few years (Dong and Sutton, 2002). In contrast, our results indicate that rainfall increases in the region adjacent to MD09-3257 occurred several hundred years after the increase in sedimentary $\mathrm{Pa} / \mathrm{Th}$ at our core site. Furthermore, this lead of sedimentary $\mathrm{Pa} / \mathrm{Th}$ over $\ln (\mathrm{Ti} / \mathrm{Ca})$ should be taken as a minimum lead of AMOC over $\ln (\mathrm{Ti} / \mathrm{Ca})$ because a change in AMOC does not instantaneously translate into a change in sedimentary $\mathrm{Pa} / \mathrm{Th}$. A delay between a change in AMOC and the resulting change in sedimentary $\mathrm{Pa} / \mathrm{Th}$ is indeed expected, which depends on the propagation time of the circulation change to the core site and on the response time of dissolved $\mathrm{Th}$ and $\mathrm{Pa}$ in the water column overlying the core site (i.e., 30-40 for ${ }^{230} \mathrm{Th}$ and $100-200 \mathrm{yr}$ for ${ }^{231} \mathrm{~Pa}$, François, 2007). However, increases or decreases in sedimentary $\mathrm{Pa} / \mathrm{Th}$ should be measurable before the dissolved Th and Pa have fully adjusted to the new circulation regime, especially at sites with high sedimentation rates such as our study site. Thus, we expect this additional delay to be less than $100 \mathrm{yr}$ and much smaller than the computed lead of MD09-3257 sedimentary $\mathrm{Pa} / \mathrm{Th}$ over $\ln (\mathrm{Ti} / \mathrm{Ca})$.

A mechanism has been proposed by Burckel et al. (2015) to explain the large lead of AMOC slowdowns during Heinrich and D-O stadials with respect to precipitation events over tropical South America. In this scenario, AMOC slowdowns are progressively amplified through a positive feedback linking the decrease in deep water formation to subsurface warming at high northern latitudes (Mignot et al., 2007; Alvarez-Solas et al., 2013), leading in the case of Heinrich stadials, to erosion of ice shelves and iceberg discharges, which in turn reinforce the initial AMOC slowdown. In contrast, AMOC slowdowns associated with $\mathrm{D}-\mathrm{O}$ stadials would not trigger such a positive feedback loop and would consequently remain limited.

Alternatively, or in addition to an actual lead of the changes in AMOC with respect to precipitation events over tropical South America, another factor could induce a lead of
$\mathrm{Pa} / \mathrm{Th}$ with respect to $\ln (\mathrm{Ti} / \mathrm{Ca})$ in core MD09-3257. It has been shown that the North Brazil Current (NBC) is able to transport terrigenous material laterally (Allison et al., 2000). Also, different studies have shown that a weakening of the AMOC is associated with a decrease of NBC transport, taking place not only on decadal timescales (Zhang et al., 2011), but also during the YD and HS1 (Arz et al., 1999; Wilson et al., 2011). Based on this evidence, a recent study suggested that a reduced NBC during HS1 allowed the enhanced input of terrigenous material to settle on the continental margin offshore of northeastern Brazil, instead of being transported northward (Zhang et al., 2015). Thus, it seems possible that terrestrial input would be deviated northward as long as the NBC was vigorous and reached the core site only once the NBC and AMOC were sufficiently reduced, thereby yielding a time-delayed peak in $\ln (\mathrm{Ti} / \mathrm{Ca})$. If this were the case, the lag of the terrestrial input signal with respect to the $\mathrm{Pa} / \mathrm{Th}$ signal would be partially or totally caused by the impact of the NBC on terrigenous material deposition (Zhang et al., 2015). Therefore, the exceptional synchronicity of the onset of terrigenous influx and AMOC slowdown at the beginning of HS1 could be due to the exceptionally large fluxes of large grain size material eroded from the proximal exposed shelf during low eustatic sea level, which would have rained down through the water column, even before full reduction of the NBC.

However, in the absence of direct measurements of the NBC velocity and vertical particle flux on the northeastern Brazilian margin, the actual delay of terrestrial input with respect to NBC slowdown remains speculative.

\subsubsection{Lag of $\delta^{13} \mathrm{C}_{\mathrm{Cw}}$ with respect to $\mathrm{Pa} / \mathrm{Th}$}

Our cross-wavelet results show that $\delta^{13} \mathrm{C}_{\mathrm{Cw}}$ lags $\mathrm{Pa} / \mathrm{Th}$ by $279 \pm 244 \mathrm{yr}(1 \sigma)$ at $\mathrm{D}-\mathrm{O}$ frequencies over $\sim 28-40 \mathrm{ka}$ at the MD09-3257 site (Table 1).

$\delta^{13} \mathrm{C}_{\mathrm{Cw}}$ is measured using $>150 \mu \mathrm{m}$ foraminifera; thus, it is carried by much larger particles than the $\mathrm{Pa} / \mathrm{Th}$ signal. Therefore, differential bioturbation mixing processes would lead to $\mathrm{Pa} / \mathrm{Th}$ being carried by sediment material younger than the epibenthic foraminifera sampled within the same depth interval. Thus, bioturbation may induce an artificial lead of $\mathrm{Pa} / \mathrm{Th}$ with respect to $\delta^{13} \mathrm{C}_{\mathrm{Cw}}$. Knowing that the sedimentation rates of MD09-3257 and GeoB3910-2 vary between 6 and $14 \mathrm{~cm}$ over the interval from 28 to $40 \mathrm{ka}$, a $280 \mathrm{yr}$ lead translates to a downward shift of 2 to $4 \mathrm{~cm}$ in the sediment column, which seems plausible for the effect of differential bioturbation.

In conclusion, the lag of $\delta^{13} \mathrm{C}_{\mathrm{Cw}}$ with respect to $\mathrm{Pa} / \mathrm{Th}$ at $\mathrm{D}-\mathrm{O}$ frequencies during $\sim 28-40 \mathrm{ka}$ is likely an artifact resulting from the differential bioturbation of fine and coarse particles. The same differential bioturbation processes likely also affect the relative phase between $\delta^{13} \mathrm{C}_{\mathrm{Cw}}$ and $\mathrm{ln}$ ( $\mathrm{Ti} / \mathrm{Ca}$ ). Thus, we will not discuss the results of the crosswavelet analyses involving $\delta^{13} \mathrm{C}_{\mathrm{Cw}}$ any further. 


\section{Conclusions}

New sedimentary $\mathrm{Pa} / \mathrm{Th}$ data from core MD09-3257 located on the northern Brazilian margin $\left(\sim 4^{\circ} \mathrm{S}, 36^{\circ} \mathrm{W}\right)$ at a depth of $\sim 2350 \mathrm{~m}$ indicate decreases in water mass transport above the core site during all Greenland stadials of the last 45 kyr. Together with two other recent studies (Gottschalk et al., 2015; Henry et al., 2016), these results demonstrate that all stadials of the last $45 \mathrm{kyr}$ were not only characterized by decreases in flow rate and extension of northern-sourced waters below a depth of $3800 \mathrm{~m}$, but also by decreases in middepth water mass transport in the western equatorial Atlantic.

Due to its exceptional location, core MD09-3257 records both ocean circulation and atmospheric changes. Ocean circulation changes induce changes in sedimentary $\mathrm{Pa} / \mathrm{Th}$ and $\delta^{13} \mathrm{C}_{\mathrm{Cw}}$, whereas changes in precipitation over the adjacent continent induce changes in marine sediments $\mathrm{Ti} / \mathrm{Ca}$.

Using cross-wavelet transforms and spectrogram analysis, we were able to precisely and robustly assess the relative phase between MD09-3257 sedimentary $\mathrm{Pa} / \mathrm{Th}$ and $\ln (\mathrm{Ti} / \mathrm{Ca})$ signals over the interval from 10 to $43 \mathrm{ka}$ with minimal uncertainty. This is owing to the fact that both signals are recorded in the same sediment core. We show that $\mathrm{Pa} / \mathrm{Th}$ leads $\ln (\mathrm{Ti} / \mathrm{Ca})$ by $259 \pm 140 \mathrm{yr}(1 \sigma)$ at $\mathrm{D}-\mathrm{O}$ frequencies over $28-40 \mathrm{ka}$, and by $631 \pm 345 \mathrm{yr}(1 \sigma)$ for periodicities close to Heinrich periodicities (4000 to $6000 \mathrm{yr}$ ) over $15-40 \mathrm{ka}$.

In other words, our cross-wavelet transforms and spectrogram analysis results show that changes in water mass transport between a depth of $\sim 1300$ and $2300 \mathrm{~m}$ in the western equatorial Atlantic (i.e., within a $\sim 1000 \mathrm{~m}$ water layer above MD09-3257 core site) preceded changes in precipitation over the adjacent continent by 110 to $400 \mathrm{yr}$ at $\mathrm{D}-\mathrm{O}$ frequencies, and by 280 to $980 \mathrm{yr}$ at Heinrich-like frequencies.

We suggest that the large lead of ocean circulation changes with respect to tropical South American precipitation changes at Heinrich-like and D-O frequencies is likely related to the action of a positive feedback in the case of Heinrich stadials, in agreement with Burckel et al. (2015). In that case, an AMOC slowdown would lead to subsurface warming at high northern latitudes, inducing ice-sheet calving and iceberg discharges that would in turn reinforce the initial AMOC slowdown. In contrast, the absence of marked ice rafted detritus layers in North Atlantic sediments during $\mathrm{D}-\mathrm{O}$ stadials suggests that in the case of $\mathrm{D}-\mathrm{O}$ stadials, AMOC slowdowns did not trigger such a positive feedback and, consequently, remained limited (Burckel et al., 2015).

Finally, the relative lead of $\mathrm{Pa} / \mathrm{Th}$ over $\ln (\mathrm{Ti} / \mathrm{Ca})$ is visible for the YD and for all Heinrich stadials, except HS1. In the case of HS1, the southward shift of the ITCZ may have been an atmospheric response to the maximum extent in northern high-latitude ice sheets and sea ice cover (Chiang et al., 2003) around that time, rather than a progressive response to a slowdown of the AMOC, as is the case for the other stadials. These different atmospheric and oceanic scenarios re- main to be tested by numerical experiments performed over several thousands of years in glacial conditions, whereby climate models compute water and calcite $\delta^{18} \mathrm{O}$, DIC $\delta^{13} \mathrm{C}$ and sedimentary $\mathrm{Pa} / \mathrm{Th}$.

Data availability. Data related to this article are available as a Supplement file and on Pangaea.

Supplement. The supplement related to this article is available online at: https://doi.org/10.5194/cp-14-1315-2018-supplement.

Author contributions. CW and SP designed the research. EB, $\mathrm{PB}, \mathrm{JL}, \mathrm{FT}$ and AD performed the sedimentary $\mathrm{Pa} / \mathrm{Th}$ measurements. BCL performed the wavelet analyses. DF and LV contributed expert advice on statistical results and performed the spectrogram analyses. LM produced the sedimentary $\mathrm{Pa} / \mathrm{Th}$ values and error bars from MC-ICP-MS output. NVR improved the age models of the two cores. CW, NVR and TD participated in the 2009 RETRO coring cruise. HWA contributed expert knowledge on the Brazilian margin. CW and TD obtained funding. CW and BL wrote the manuscript.

Competing interests. The authors declare that they have no conflict of interest.

Acknowledgements. This is a contribution to the ACCLIMATE ERC project; the research leading to these results has received funding from the European Research Council under the European Union's Seventh Framework Programme (FP7/2007-2013)/ERC grant agreement no. 339108. Core MD09-3257 was collected on board R/V Marion Dufresne during the 2009 RETRO coring cruise, supported by IPEV, ANR project ANR-09-BLAN-0347 and the ESF EUROMARC project "RETRO". We thank the IPEV team, crew members of R/V Marion Dufresne and all scientists who participated in the 2009 RETRO cruise. We also thank Matthieu Roy-Barman for advice regarding Pa / Th measurements from the LSCE MC-ICP-MS. We acknowledge Vincent Scao and Jørund Strømsøe for XRF measurements, Christophe Moreau, JeanPascal Dumoulin, and the UMS ARTEMIS for AMS ${ }^{14} \mathrm{C}$ dates, as well as Gülay Isguder, Lucile Mauclair and Fabien Dewilde for invaluable technical assistance. We are grateful to Roger François and one anonymous reviewer for their helpful comments on an earlier version of this article. This paper is LSCE contribution 6408.

Edited by: Luc Beaufort

Reviewed by: Roger Francois and one anonymous referee 


\section{References}

Allison, M. A., Lee, M. T., Ogston, A. S., and Aller, R. C.: Origin of Amazon mudbanks along the northeastern coast of South America, Mar. Geol., 163, 241-256, 2000.

Alvarez-Solas, J., Robinson, A., Montoya, M., and Ritz, C.: Iceberg discharges of the last glacial period driven by oceanic circulation changes, P. Natl. Acad. Sci. USA, 110, 16350-16354, https://doi.org/10.1073/pnas.1306622110, 2013.

Anderson, R., Fleisher, M., and Lao, Y.: Glacial-interglacial variability in the delivery of dust to the central equatorial Pacific Ocean, Earth Planet. Sc. Lett., 242, 406-414, 2006.

Arz, H. W., Pätzold, J., and Wefer, G.: Correlated Millennial-Scale Changes in Surface Hydrography and Terrigenous Sediment Yield Inferred from Last-Glacial Marine Deposits off Northeastern Brazil, Quaternary Res., 50, 157-166, 1998.

Arz, H. W., Pätzold, J., and Wefer, G.: The deglacial history of the western tropical Atlantic as inferred from high resolution stable isotope records off northeastern Brazil, Earth Planet. Sc. Lett., 167, 105-117, 1999.

Arz, H. W., Gerhardt, S., Pätzold, J., and Röhl, U.: Millennial-scale changes of surface- and deep-water flow in the western tropical Atlantic linked to Northern Hemisphere high-latitude climate during the Holocene, Geology, 29, 239-242, 2001.

Bourillet, J.-F., Damy, G., Dussud, L., Sultan, N., Woerther, P., and Migeon, S.: Behaviour Of A Piston Corer From Accelerometers And New Insights On Quality Of The Recovery., Proc. 6th Int. Off shore Site Investig, Geotech. Conf., Confronting New Challenges Shar, Knowledge, 11-13 September 2007, London, UK, available at: http://archimer.ifremer.fr/doc/00071/ 18198/ (last access: 14 September 2018), 2007.

Bronk Ramsey, C.: Deposition models for chronological records, Quaternary Sci. Rev., 27, 42-60, 2008.

Brown, L., Cook, G. T., MacKenzie, A. B., and Thomson, J.: Radiocarbon age profiles and size dependency of mixing in northeast Atlantic sediments, Radiocarbon, 43, 929-937, 2001.

Burckel, P., Waelbroeck, C., Gherardi, J.-M., Pichat, S., Arz, H., Lippold, J., Dokken, T., and Thil, F.: Atlantic Ocean circulation changes preceded millennial tropical South America rainfall events during the last glacial, Geophys. Res. Lett., 42, 411-418, 2015.

Chase, Z., Anderson, R. F., Fleisher, M. Q., and Kubik, P. W.: The influence of particle composition and particle flux on scavenging of Th, Pa and Be in the ocean, Earth Planet. Sc. Lett., 204, 215229, 2002.

Cheng, H., Sinha, A., Cruz, F. W., Wang, X., Edwards, R. L., d'Horta, F. M., Ribas, C. C., Vuille, M., Stott, L. D., and Auler, A. S.: Climate change patterns in Amazonia and biodiversity, Nat. Commun., 4, 1411-1417, https://doi.org/10.1038/ncomms2415, 2013.

Chiang, J. C. H., Biasutti, M., and Battisti, D. S.: Sensitivity of the Atlantic Intertropical Convergence Zone to Last Glacial Maximum boundary conditions, Paleoceanography, 18, 1-18, https://doi.org/10.1029/2003PA000916, 2003.

Croudace, I. W. and Rothwell, R. G. (Eds.): Micro-XRF Studies of Sediment Cores: Applications of a non-destructive tool for the environmental sciences, Dev. in Paleoenviron. Res., Springer, 17, 656 pp., 2015.
Davis, J. C.: Statistics and data analysis in geology, J. Wiley, New York, 646 pp., 1986.

DeMaster, D. J. and Cochran, J. K.: Particle mixing rates in deepsea sediments determined from excess ${ }^{210} \mathrm{~Pb}$ and ${ }^{32} \mathrm{Si}$ profiles, Earth Planet. Sc. Lett., 61, 257-271, 1982.

Dong, B. W. and Sutton, R.: Adjustment of the coupled oceanatmosphere system to a sudden change in the thermohaline circulation, Geophys. Res. Lett., 29, 18-1-18-4, 2002.

Duplessy, J.-C., Shackleton, N. J., Matthews, R. K., Prell, W., Ruddiman, W. F., Caralp, M., and Hendy, C. H.: ${ }^{13} \mathrm{C}$ record of benthic foraminifera in the last interglacial ocean: implications for the carbon cycle and the global deep water circulation, Quaternary Res., 21, 225-243, 1984.

Duplessy, J.-C., Shackleton, N. J., Fairbanks, R. G., Labeyrie, L., Oppo, D., and Kallel, N.: Deepwater source variations during the last climatic cycle and their impact on the global deepwater circulation, Paleoceanography, 3, 343-360, 1988.

Eide, M., Olsen, A., Ninnemann, U. S., and Johannessen, T.: A global ocean climatology of preindustrial and modern ocean $\delta^{13}$ C, Global Biogeochem. Cy., 31, 515-534, 2017.

François, R.: Chapter Sixteen Paleoflux and Paleocirculation from Sediment ${ }^{230} \mathrm{Th}$ and ${ }^{231} \mathrm{~Pa} /{ }^{230} \mathrm{Th}$, Dev. Mar. Geol., 1, 681-716, 2007. s

François, R., Frank, M., Rutgers van der Loeff, M. M., and Bacon, M. P.: ${ }^{230}$ Th normalization: An essential tool for interpreting sedimentary fluxes during the late Quaternary, Paleoceanography, 19, 1-16, 2004.

Freeman, E., Skinner, L. C., Waelbroeck, C., and Hodell, D.: Radiocarbon evidence for enhanced respired carbon storage in the Atlantic at the Last Glacial Maximum, Nat. Commun., 7, 1-8, https://doi.org/10.1038/ncomms11998, 2016.

Gerhardt, S., Groth, H., Rühlemann, C., and Henrich, R.: Aragonite preservation in late Quaternary sediment cores on the Brazilian Continental Slope: implications for intermediate water circulation, Int. J. Earth Sci., 88, 607-618, 2000.

Gottschalk, J., Skinner, L. C., Misra, S., Waelbroeck, C., Menviel, L., and Timmermann, A.: Abrupt changes in the southern extent of North Atlantic Deep Water during Dansgaard-Oeschger events, Nat. Geosci., 8, 950-954, https://doi.org/10.1038/ngeo2558, 2015.

Grinsted, A., Moore, J. C., and Jevrejeva, S.: Application of the cross wavelet transform and wavelet coherence to geophysical time series, Non. Proc. Geophys., 11, 561-566, 2004.

Guihou, A., Pichat, S., Nave, S., Govin, A., Labeyrie, L., Michel, E., and Waelbroeck, C.: Late slowdown of the Atlantic Meridional Overturning Circulation during the Last Glacial Inception: new constraints from sedimentary $\left({ }^{231} \mathrm{~Pa} /{ }^{2303} \mathrm{Th}\right)$, Earth Planet. Sc. Lett., 289, 520-529, 2010.

Heil, G.: Abrupt climate shifts in the western tropical to subtropical Atlanic region during the last glacial, $\mathrm{PhD}$ Thesis, Bremen University, 121 pp., 2006.

Henderson, G. M. and Anderson, R. F.: The U-series toolbox for paleoceanography, Rev. Mineral. Geochem., 52, 493-531, 2003.

Henry, L., McManus, J. F., Curry, W. B., Roberts, N. L., Piotrowski, A. M., and Keigwin, L. D.: North Atlantic ocean circulation and abrupt climate change during the last glaciation, Science, 353, 470-474, 2016.

Jaeschke, A., Rühlemann, C., Arz, H., Heil, G., and Lohmann, G.: Coupling of millennial-scale changes in sea surface temperature 
and precipitation off northeastern Brazil with high-latitude climate shifts during the last glacial period, Paleoceanography, 22, PA4206, https://doi.org/10.1029/2006PA001391, 2007.

Johnsen, S., Clausen, H. B., Dansgaard, W., Fuhrer, K., Gundestrup, N., Hammer, C. U., Iversen, P., Jouzel, J., and Stauffer, B.: Irregular glacial interstadials recorded in a new Greenland ice core, Nature, 359, 311-313, 1992.

Key, R. M., Kozyr, A., Sabine, C. L., Lee, K., Wanninkhof, R., Bullister, J. L., Feely, R. A., Millero, F. J., Mordy, C., and Peng, T. H.: A global ocean carbon climatology: Results from Global Data Analysis Project (GLODAP), Global Biogeochem. Cy., 18, 1-23, 2004.

Kindler, P., Guillevic, M., Baumgartner, M., Schwander, J., Landais, A., and Leuenberger, M.: Temperature reconstruction from 10 to 120 kyr b2k from the NGRIP ice core, Clim. Past, 10, 887-902, https://doi.org/10.5194/cp-10-887-2014, 2014.

Kretschmer, S., Geibert, W., van der Loeff, M. M. R., and Mollenhauer, G.: Grain size effects on ${ }^{230} \mathrm{Th}$ xs inventories in opalrich and carbonate-rich marine sediments, Earth Planet. Sc. Lett., 294, 131-142, 2010.

Langehaug, H., Mjell, T., Otterå, O., Eldevik, T., Ninnemann, U., and Kleiven, H.: On the reconstruction of ocean circulation and climate based on the "Gardar Drift", Paleoceanography, 31, 399 415,2016

Lippold, J., Gherardi, J.-M., and Luo, Y.: Testing the ${ }^{231} \mathrm{PA} /{ }^{230} \mathrm{Th}$ paleocirculation proxy: A data versus 2D model comparison, Geophys. Res. Lett., 38, 1-7, https://doi.org/10.1029/2011GL049282, 2011.

Lippold, J., Mulitza, S., Mollenhauer, G., Weyer, S., Heslop, D., and Christl, M.: Boundary scavenging at the East Atlantic margin does not negate use of ${ }^{231} \mathrm{PA} /{ }^{230} \mathrm{Th}$ to trace Atlantic overturning, Earth Planet. Sc. Lett., 333, 317-331, 2012.

Lougheed, B. C., Metcalfe, B., Ninnemann, U. S., and Wacker, L.: Moving beyond the age-depth model paradigm in deepsea palaeoclimate archives: dual radiocarbon and stable isotope analysis on single foraminifera, Clim. Past, 14, 515-526, https://doi.org/10.5194/cp-14-515-2018, 2018.

Luo, Y., Francois, R., and Allen, S. E.: Sediment ${ }^{231}$ PA / ${ }^{230} \mathrm{Th}$ as a recorder of the rate of the Atlantic meridional overturning circulation: insights from a 2-D model, Ocean Sci., 6, 381-400, https://doi.org/10.5194/os-6-381-2010, 2010.

Lux, M., Mercier, H., and Arhan, M.: Interhemispheric exchanges of mass and heat in the Atlantic Ocean in January-March 1993, Deep-Sea Res. Pt. I, 48, 605-638, 2001.

Lynch-Stieglitz, J., Stocker, T., Broecker, W. S., and Fairbanks, R. G.: The influence of air-sea exchange on the isotopic composition of oceanic carbon: Observations and modeling, Global Biogeochem. Сy., 9, 653-665, 1995.

McCave, I.: Biological pumping upwards of the coarse fraction of deep-sea sediments, J. Sediment. Res., 58, 148-158, 1988.

Mignot, J., Ganopolski, A., and Levermann, A.: Atlantic subsurface temperatures: Response to a shutdown of the overturning circulation and consequences for its recovery, J. Clim., 20, 4884-4898, 2007.

Milliman, J. D., Summerhayes, C. P., and Barretto, H. T.: Quaternary sedimentation on the Amazon continental margin: a model, Geol. Soc. Am. Bull., 86, 610-614, 1975.

Missiaen, L., Pichat, S., Waelbroeck, C., Douville, E., Bordier, L., Dapoigny, A., Thil, F., Foliot, L., and Wacker, L.: Downcore variations of sedimentary detrital $\left({ }^{238} \mathrm{U} /{ }^{232} \mathrm{Th}\right)$ ratio: implications on the use of ${ }^{230}$ Thxs and ${ }^{231}$ Paxs to reconstruct sediment flux and ocean circulation, Geochem. Geophy. Geosy., 19, 1-14, https://doi.org/10.1029/2017GC007410, 2018

Mulitza, S., Chiessi, C. M., Schefuß, E., Lippold, J., Wichmann, D., Antz, B., Mackensen, A., Paul, A., Prange, M., and Rehfeld, K.: Synchronous and proportional deglacial changes in Atlantic Meridional Overturning and northeast Brazilian precipitation, Paleoceanography, 32, 622-633, 2017.

Rasmussen, S. O., Bigler, M., Blockley, S. P., Blunier, T., Buchardt, S. L., Clausen, H. B., Cvijanovic, I., Dahl-Jensen, D., Johnsen, S. J., and Fischer, H.: A stratigraphic framework for abrupt climatic changes during the Last Glacial period based on three synchronized Greenland ice-core records: refining and extending the INTIMATE event stratigraphy, Quaternary Sci. Rev., 106, 14-28, 2014.

Reimer, P., Bard, E., Bayliss, A., Beck, J. W., Blackwell, P. G., Bronk Ramsey, C., Buck, C. E., Cheng, H., Edwards, R. L., Friedrich, M., Grootes, P. M., Guilderson, T. P., Haflidason, H., Hajdas, I., Hatté, C., Heaton T. J., Hoffmann, D. L., Hogg, A. G., Hughen, K. A., Kaiser, K. F., Kromer, B., Manning, S. W., Niu, M., Reimer, R. W., Richards, D. A., Scott, E. M., Southon, J. R., Staff, R. A., Turney, C. S. M., and van der Plicht, J.: IntCal13 and Marine13 radiocarbon age calibration curves $0-50,000$ years cal BP, Radiocarbon, 55, 1869-1887, 2013.

Rhein, M., Kieke, D., and Steinfeldt, R.: Advection of North Atlantic Deep Water from the Labrador Sea to the southern hemisphere, J. Geophys. Res.-Ocean., 120, 2471-2487, 2015.

Rühlemann, C., Frank, M., Hale, W., Mangini, A., Mulitza, S., Müller, P., and Wefer, G.: Late Quaternary productivity changes in the western equatorial Atlantic: Evidence from ${ }^{230} \mathrm{Th}-$ normalized carbonate and organic carbon accumulation rates, Mar. Geol., 135, 127-152, 1996.

Schmittner, A., Bostock, H. C., Cartapanis, O., Curry, W. B., Filipsson, H. L., Galbraith, E. D., Gottschalk, J., Herguera, J. C., Hoogakker, B., Jaccard, S. L., Lisiecki, L. E., Lund, D. C., Martínez-Méndez, G., Lynch-Stieglitz, J., Mackensen, A., Michel, E., Mix, A. C., Oppo, D. W., Peterson, C. D., Repschläger, J., Sikes, E. L., Spero, H. J., and Waelbroeck, C.: Calibration of the carbon isotope composition $\left(\delta^{13} \mathrm{C}\right)$ of benthic foraminifera, Paleoceanography, 32, 512-530, https://doi.org/10.1002/2016PA003072, 2017.

Scholten, J., Botz, R., Paetsch, H., and Stoffers, P.: 230Thex flux into Norwegian-Greenland Sea sediments: Evidence for lateral sediment transport during the past 300,000 years, Earth Planet. Sc. Lett., 121, 111-124, 1994.

Schott, F. A., Dengler, M., Brandt, P., Affler, K., Fischer, J., Bourles, B., Gouriou, Y., Molinari, R. L., and Rhein, M.: The zonal currents and transports at $35 \mathrm{~W}$ in the tropical Atlantic, Geophys. Res. Lett., 30, 1-4, 2003.

Sepulcre, S., Durand, N., and Bard, E.: Large ${ }^{14} \mathrm{C}$ age offsets between the fine fraction and coexisting planktonic foraminifera in shallow Caribbean sediments, Quaternary Geochronol., 38, 6174, 2017.

Taylor, S. and McLennan, S.: The continental crust: its composition and evolution, Oxford, Blackwell Press, 312 pp., 1985.

Thomas, A. L., Henderson, G. M., and Robinson, L. F.: Interpretation of the ${ }^{231} \mathrm{~Pa} /{ }^{230} \mathrm{Th}$ paleocirculation proxy: New water- 
column measurements from the southwest Indian Ocean, Earth Planet. Sc. Lett., 241, 493-504, 2006.

Thomson, J., Colley, S., Anderson, R., Cook, G., MacKenzie, A., and Harkness, D.: Holocene sediment fluxes in the northeast Atlantic from ${ }^{230}$ Thexcess and radiocarbon measurements, Paleoceanography, 8, 631-650, 1993.

Thornalley, D. J. R., Barker, S., Broecker, W. S., Elderfield, H., and McCave, I. N.: The Deglacial Evolution of North Atlantic Deep Convection, Science, 331, 202-205, 2011.

Torrence, C. and Compo, G. P.: A practical guide to wavelet analysis, B. Am. Meteorol. Soc., 79, 61-78, 1998.

Torrence, C. and Webster, P. J.: Interdecadal changes in the ENSOmonsoon system, J. Clim., 12, 2679-2690, 1999.

Vazquez Riveiros, N., Waelbroeck, C., Roche, D. M., Moreira, S., Burckel, P., Dewilde, F., Skinner, L., Böhm, E., Arz, H. W., and Dokken, T.: Northern origin of western tropical Atlantic deep waters during Heinrich Stadials, submitted, 2018.

Vidal, L., Labeyrie, L., Cortijo, E., Arnold, M., Duplessy, J. C., Michel, E., Becqué, S., and van Weering, T. C. E.: Evidence for changes in the North Atlantic Deep Water linked to meltwater surges during the Heinrich events, Earth Planet. Sc. Lett., 146, 13-26, 1997.

Waelbroeck, C., Duplessy, J.-C., Michel, E., Labeyrie, L., Paillard, D., and Duprat, J.: The timing of the last deglaciation in North Atlantic climate records, Nature, 412, 724-727, 2001.

Weltje, G. J. and Tjallingii, R.: Calibration of XRF core scanners for quantitative geochemical logging of sediment cores: theory and application, Earth Planet. Sc. Lett., 274, 423-438, 2008.
Wheatcroft, R. A.: Experimental tests for particule size-dependent bioturbation in the deep ocean, Limnol. Oceanogr., 37, 90-104, 1992.

Wilson, K. E., Maslin, M. A., and Burns, S. J.: Evidence for a prolonged retroflection of the North Brazil Current during glacial stages, Palaeogeogr. Palaeocl., 301, 86-96, 2011.

Woerther, P. and Bourillet, J. F.: Exploitation des mesures faites avec les accéléromètres sur le carottier CAPYPSO-Mission SEDICAR4-ALIENOR, Ifremer, Brest, 47 pp., 2005.

Yu, E.-F., François, R., and Bacon, M.: Similar rates of modern and last-glacial ocean thermohaline circulation inferred from radiochemical data, Nature, 379, 689-694, 1996.

Zahn, R., Winn, K., and Sarnthein, M.: Benthic foraminiferal $\delta^{13} \mathrm{C}$ and accumulation rates of organic carbon: Uvigerina peregrina group and Cibicidoides wuellerstorfi, Paleoceanography, 1, 2742, 1986.

Zhang, D., Msadek, R., McPhaden, M. J., and Delworth, T.: Multidecadal variability of the North Brazil Current and its connection to the Atlantic meridional overturning circulation, J. Geophys. Res.-Ocean., 116, 1-9, 2011.

Zhang, Y., Chiessi, C. M., Mulitza, S., Zabel, M., Trindade, R. I., Hollanda, M. H. B., Dantas, E. L., Govin, A., Tiedemann, R., and Wefer, G.: Origin of increased terrigenous supply to the NE South American continental margin during Heinrich Stadial 1 and the Younger Dryas, Earth Planet. Sc. Lett., 432, 493-500, 2015. 